Bryn Mawr College

Scholarship, Research, and Creative Work at Bryn Mawr

College

History of Art Faculty Research and Scholarship

History of Art

2002

\title{
The horse, the king and the cuckoo: medieval narrations of the statue of Marcus Aurelius
}

Dale Kinney

Bryn Mawr College, dkinney@brynmawr.edu

Let us know how access to this document benefits you.

Follow this and additional works at: https://repository.brynmawr.edu/hart_pubs

Part of the History of Art, Architecture, and Archaeology Commons

\section{Custom Citation}

Kinney, Dale. 2002. "The horse, the king and the cuckoo: medieval narrations of the statue of Marcus Aurelius." Word \& Image 18.1: 372-398.

This paper is posted at Scholarship, Research, and Creative Work at Bryn Mawr College. https://repository.brynmawr.edu/hart_pubs/95

For more information, please contact repository@brynmawr.edu. 


\title{
The horse, the king and the cuckoo: medieval narrations of the statue of Marcus Aurelius
}

\author{
DALE KINNEY
}

For Phyllis Bober*

\section{Prologue}

When a work of art loses its home it goes into a museum; that is the most civilized solution.... ${ }^{\mathrm{I}}$

The equestrian statue of Marcus Aurelius (figure I) became homeless in 198I, when on a frigid January morning the horse was lifted from its base in the center of the Piazza del Campidoglio and paraded to the Istituto Centrale del Restauro in Trastevere. After years of preliminary study, the statue was cleaned and restored in $1987-88$, in time to be returned to the Capitol on the 45oth anniversary of its original installation there by order of Pope Paul $\mathrm{III}$ in $\mathrm{I} 538$. The reinstallation never occurred, however, because the conservators had determined that the bronze was too susceptible to further degradation by Roman air pollution to be displayed in open air. When the statue was brought back to the Capitol in 1990, it was to a nook off the courtyard of the Museo Capitolino, where it was sealed behind glass (figures 2 and 3 ). In 1997 a replica took its place on Michelangelo's pedestal in the center of the glorious Piazza (figure 4). ${ }^{2}$

Like many major monuments, the statue of Marcus Aurelius was well known but imperfectly studied. ${ }^{3}$ Its availability in the laboratory coincided with, and was in part responsible for, a sudden swell of publication that included some careful re-examinations of the statue's postclassical afterlife. One especially colorful document of that afterlife, an etiological tale found first in the mid-twelfth century text called Mirabilia urbis Romae, was analyzed in particular by Chiara Frugoni, Norberto Gramaccini, and Ingo Herklotz, all of whom interpreted it as an instrument of papal or antipapal propaganda. Since the mid-I980s it has been taken for granted that the twelfth-century story was composed by a member of one or another of Rome's medieval factions, to advocate one or another political position. ${ }^{4}$

My own engagement with this story dates to I986, when I was asked to participate in a lecture series called 'Living Classics'. ${ }^{5}$ I chose to speak on the reception of the statue of Marcus Aurelius because the topic seemed to offer a synecdoche for the fate of the classical tradition in the West. The more I studied the Mirabilia urbis Romae while preparing this lecture, the more convinced I became that its tale about the equestrian statue is what it purports to be: an attempt to deduce the statue's historical meaning, rather than a calculated instrument of eleventh- or twelfth-century politics. I also came to see that the synecdochic parable I had planned to tell was not so simple. The paradigm of the loss of classical culture (epitomized by the ability to recognize the statue as Marcus Aurelius) in the Middle Ages and its recovery by humanists in the Renaissance is a good fit so long as 'culture' is narrowly equated with biography. The biographies of Roman emperors and the ability to match their names with physiognomies are indeed forms of knowledge that were lost or abandoned by medievals and laboriously recovered by the revolutionary scholarship of the fifteenth and sixteenth centuries. But biographical interpretation, validated by these efforts and consequently by traditional iconography, is only one key to the signifying system of a monument like the statue of Marcus Aurelius. It is focused on just one aspect of what Roland Barthes has called the 'coded iconic message' of an image, namely signifiers of identity and personality; it does not address other coded features, nor does it treat the 'message without a code', 'a matter of almost anthropological knowledge' on the part of the interpreter. ${ }^{6}$

In semiotic terms, historical identification pertains to the literal image and its denotation. Medievals, having lost the tools to decipher the literal level of the commemorative statue, had to approach it through its connotations, without the anchor provided by the denotative meaning. I hope to persuade readers of this essay that the interpretation constructed from those unfettered connotations, recorded in the Mirabilia urbis Romae and its variants, is interesting as an illustration of the 'dysfunction' posited by Barthes as a necessary product of polysemy. ${ }^{7}$ The dysfunction bedevils all belated interpreters of the statue, not only medieval ones.

\section{Background}

The mainstream tradition of late classical historiography is very favorable to Marcus Aurelius, beginning in the third century with his near contemporary Cassius Dio (229) and continuing with Aurelius Victor (c. 360), Eutropius (369), Ammianus Marcellinus (390), and the biography by 'Julius Capitolinus' in the Historia Augusta (c. 400?). ${ }^{8}$ In these accounts Marcus, though frail of body and beset by constant warfare, natural disasters, and an unfaithful wife, was the best of 


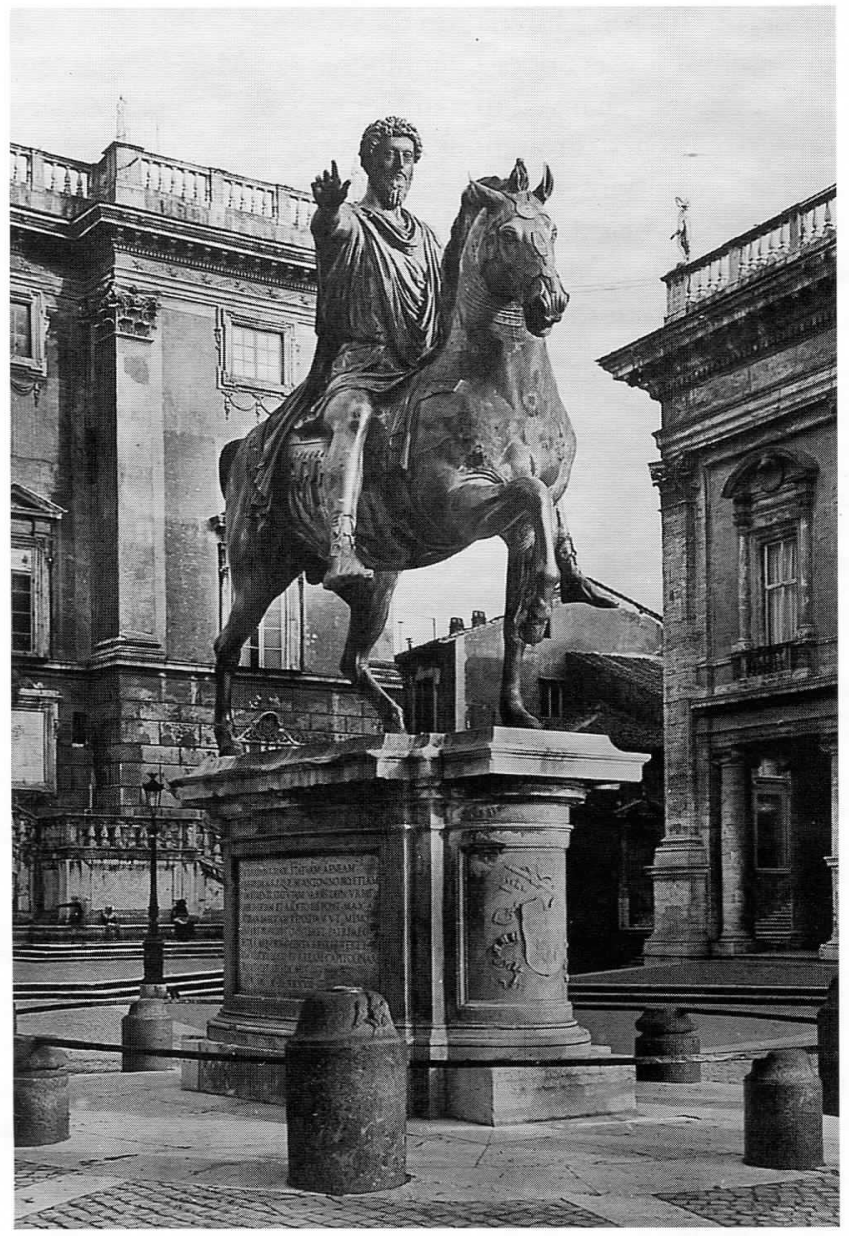

Figure I. Rome, Piazza del Campidoglio, equestrian statue of Marcus Aurelius. Photo: Deutsches Archäologisches Institut, Rome.

emperors, magnanimous, temperate, diligent, and humane. Cassius Dio famously pronounced the transition from his reign to that of his son Commodus a descent 'from a kingdom of gold to one of iron and rust'. 9 The emperor was

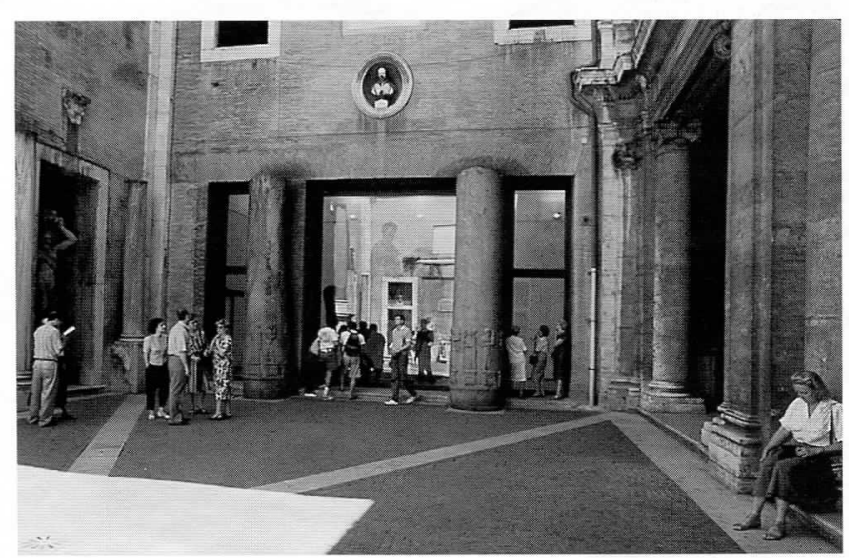

Figure 2. Rome, Museo Capitolino, view toward equestrian statue behind glass, 1990. Photo: author.

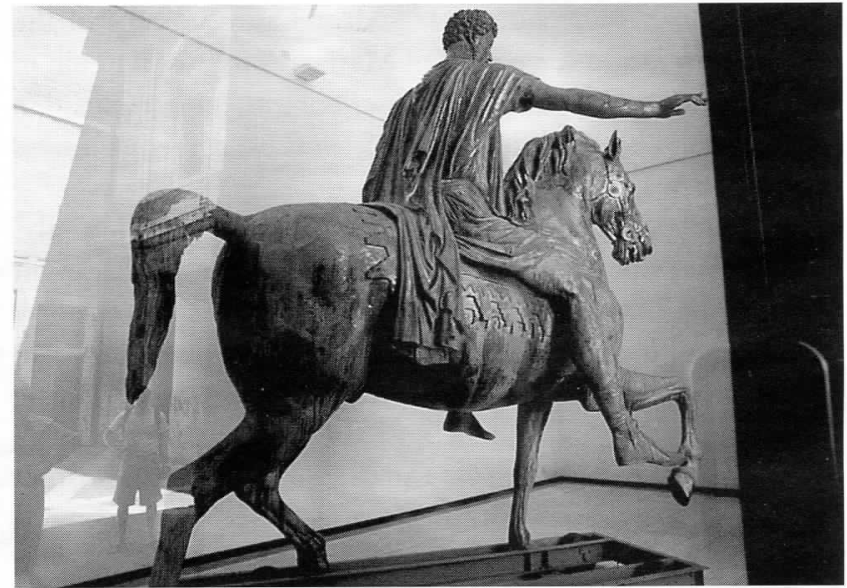

Figure 3. Rome, Museo Capitolino, equestrian statue through glass, I990. Photo: author.

especially appreciated in the latter part of the fourth century by the traditionalist senatorial aristocracy of Rome and by their ineffective avatar, Julian $(36 \mathrm{I}-363)$, who fancied himself a fellow philosopher and proclaimed Marcus Aurelius his ideal. ${ }^{10}$ The surviving Latin tradition of Marcus-eulogy comes from this period and milieu.

The commendatory view of Marcus Aurelius was largely unavailable in the Latin Middle Ages. Cassius Dio continued to be read in Byzantium, and the emperor's intimate notebook 'To Himself', also in Greek, surfaced around 900 in the possession of the scholar Arethas, archbishop of Caesarea in Cappadocia. ${ }^{\text {II }}$ But in the West the substantial accounts were lost. The first books of Ammianus Marcellinus' Res gestae had disappeared by the ninth century. ${ }^{\text {I2 }}$ The Historia Augusta, probably clandestine to begin with, was copied sporadically in Carolingian monasteries and Ottonian courts but remained obscure until Giovanni de Matociis used it

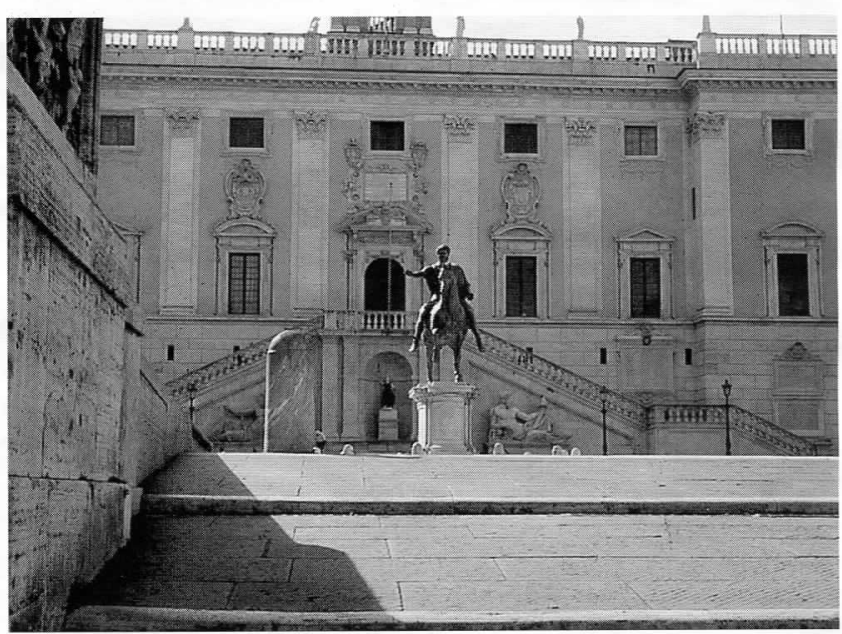

Figure 4. Rome, Piazza del Campidoglio, replica of statue of Marcus Aurelius, 1998. Photo: author. 
for his Imperial History of $13 \mathrm{I} 3 .{ }^{\mathrm{I}}{ }^{3}$ Most Latin literates of the middle ages would have read of Marcus Aurelius, if at all, in Eutropius' Breviarium, which was a school text, and in Christian sources, notably the fifth-century Seven Books of History Against the Pagans by Paulus Orosius.

Christian sources present the emperor very differently. Orosius describes his reign as the time of the fourth great persecution after Nero, for which God exacted retribution by means of a terrible plague. The emperor was forced to acknowledge the power of this Christian God when his army was miraculously refreshed, and the enemy routed, by a thunderstorm brought on by the prayers of some Christian soldiers. A letter testifying to the miracle and purporting to be from Marcus himself was said to be still in circulation in Orosius' own time. ${ }^{14}$ A version of it has survived as an apocryphal appendix to the Apology of Justin addressed to Marcus' predecessor Antoninus Pius (r. I38-r6I). ${ }^{15}$ It must go back to an original fabricated in Marcus' lifetime, possibly on the basis of the official report of a real event represented with creepy anthropomorphism on the emperor's triumphal column (figure 5). Cassius Dio ascribed the same unnatural weather to the intervention of Mercury, invoked by the charms of an Egyptian magician. ${ }^{16}$

The Christian appropriation of the storm miracle was known to Tertullian, whose own Apology (I97-I98) holds up Marcus Aurelius as a 'protector' of Christians on the grounds that while he did not change their (il)legal status, he made it a capital crime to accuse them. ${ }^{17}$ In the fourth century Eusebius recounted the miracle following a long series of ostensibly eyewitness accounts of horrific persecutions under the emperor 'Antoninus Verus' in Asia and Gaul. The miraculous storm is a non sequitur, so unlike the rest of this reign that Eusebius seems to ascribe it to a different

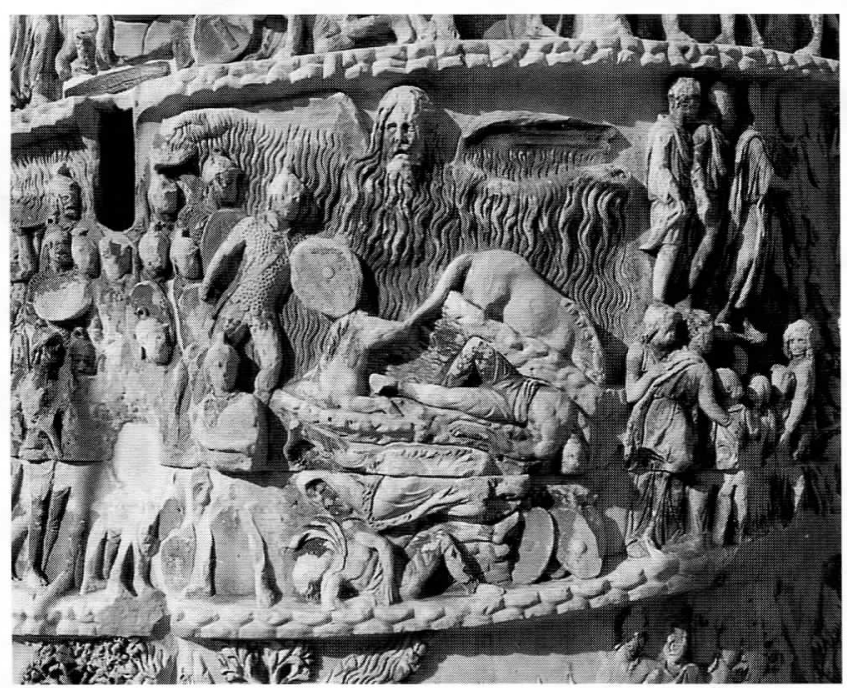

Figure 5. Rome, triumphal column of Marcus Aurelius, detail. Photo: DAI, Neg. 89206. emperor, 'his son Marcus Aurelius Caesar'. ${ }^{18}$ But according to Eusebius it was under Commodus, not Marcus, that 'our treatment was changed to a milder one, and ... peace came on the churches throughout the world'. ${ }^{\text {19 }}$

The executions of Christians documented by Eusebius actually occurred, including the death of Justin, the philosopher-turned-Christian apologist, in Rome itself. ${ }^{20}$ Marcus Aurelius did nothing to stop them. 'If he considered their beliefs at all' it probably was not favorably; his own Stoic virtues were at odds with theirs, and Christians' behavior must have been incomprehensible to him. ${ }^{21}$ Late in his reign he underwent initiation at Eleusis. Pace the legend of the storm, Christians had no reason to commemorate Marcus Aurelius, let alone celebrate him. For his part, the emperor would have been mortified to know that for more than a millennium his statue was one of the most precious ornaments of the Roman church, standing for centuries outside the cathedral before its transfer to a thoroughly Christianized Capitol in $153^{8}$.

Even the most learned medieval observer lacked the means to connect the Marcus Antoninus Verus of Christian history with the bronze equestrian statue that we today call Marcus Aurelius. ${ }^{22}$ The modern identification rests on the portrait, and it required centuries of patient collecting and collation of labeled coin types to achieve (figure 6). ${ }^{23}$ Without this foundation, a precocious proto-archaeologist might conceivably have noticed a resemblance between the head of the statue and the many depictions of the emperor in the spiral reliefs on his posthumous honorific column, which was known by his name ('Column of Antoninus') throughout the Middle Ages and represents, among its hundreds of scenes, the miracle Orosius describes. ${ }^{24}$ If this did not happen, it was not only because the portraits on the column are so hard to see. ${ }^{25}$ The mental habits required to seek out correlations among unnamed artifacts, texts, and other artifacts did not yet exist.

Medieval viewers came upon the emperor's statue in the Campus Lateranensis, a shapeless opening between the Arcus Caelimontani (a branch of the Claudian aqueduct) and the papal palace on the north side of the cathedral
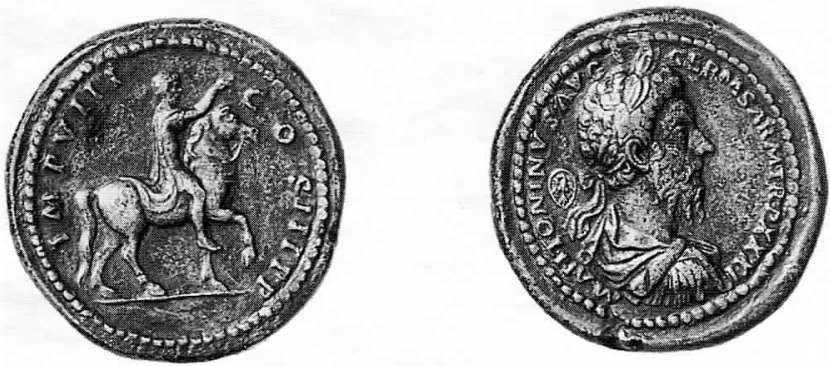

Figure 6. Milan, Civiche Raccolte Archeologiche e Numismatiche, bronze medallion of Marcus Aurelius, 177, reverse and obverse. Photo: Civiche Raccolte, courtesy Rodolfo Martini. 
1. Portique.

2. Oratoire Saint-Thomas.

4. Porta Santa.

6. Ancien chœur des chanoines (tombeau de Martin V).

7. Ambons.

8. Autel des $\mathbf{4 0}$ martyrs.

9. Autel de saint Antonin.

10. Autel de Notre-Dame del Riposo.

11. Accès à la Salle du Concile.

13. Autel des saints Chrysanthe et Darius.

14. Autel de sainte Marie-Madeleine.

15. Confession.

16. Autel papal (en bois).
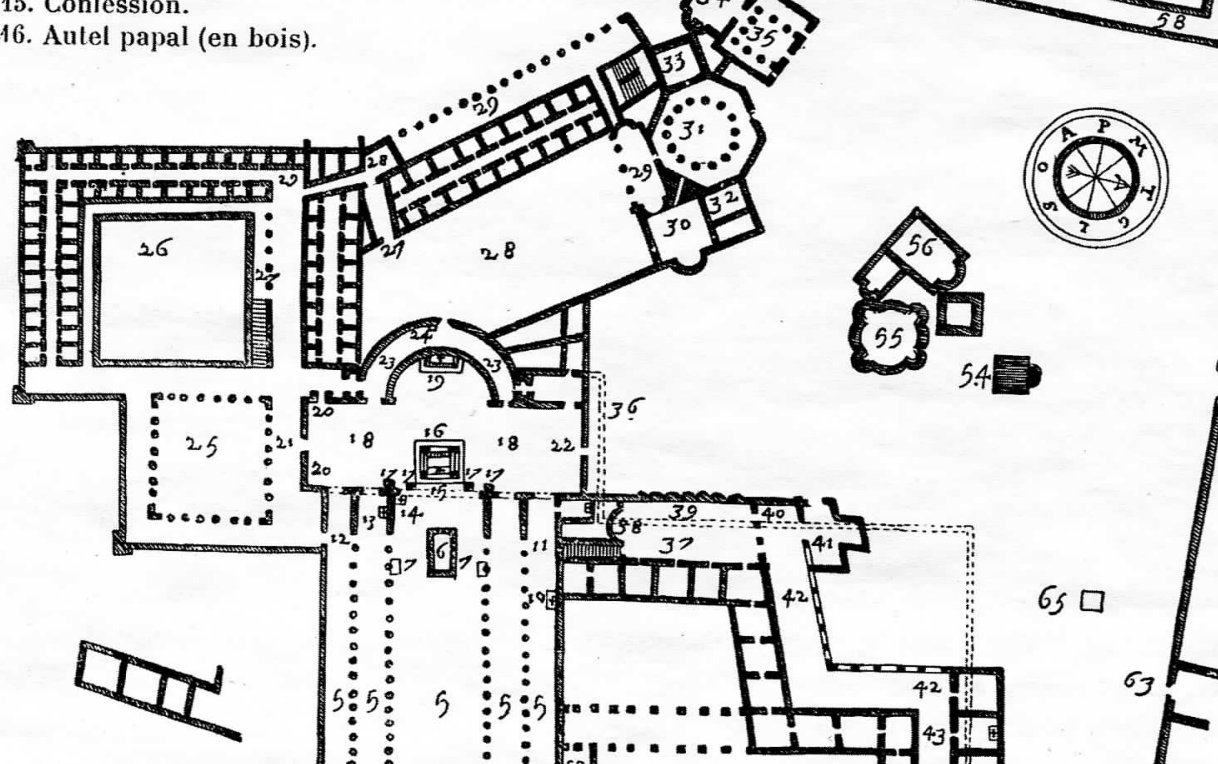

17. Colonnes d'airain (actuellement à

l'autel du Saint-Sacrement).

19. Siège pontifical.

20. Ancien chœur des chanoines réguliers de Saint-Augustin (audessous de l'orgue).

24. Sarcophage de l'impératrice Hélène.

26. Monastère du Latran.

27. Monastère Saint-Pancrace.

29. Portique de Saint-Venance.

30. Oratoire de Saint-Venance.

31. Baptistère du Latran.

3\%. Oratoire de Sainte-Croix.

37. Salle du Concile.

40. Les trois portes saintes « du Palais de Pilate ^ et autel de la Vierge.

41. Loge des Bénédictions.

42. Ambulacre.

43. Oratoire Saint-Sylvestre.

44. Scala Sanla.

$$
\begin{array}{ll}
\text { dautres édifices (?) } & \text { 65. Statue équestro } \\
\text { FIG. 113. - Plan du Latran par Contini (CIAMPINI, De sacris ædif., tab. III). }
\end{array}
$$

47. Portique du palais.

48. Vestibule devant le Sancla Sanctorum.

49. Oratoire Saint-Laurent.

50. Trielinium de Léon III.

31. Oratoire Saint-Nicolas.

53. Place de l'obélisque actuel.

55. Vestiges de la tour dite des Anibaldi.

56. Vestiges de l'église Saint-Ange et
58. Monastère des Saints-Barthélemyet-André, élevé par Honorius Ier (devenu Xenodochium, puis hôpital).

63. Daterie et services pontificaux.

64. Aqueduc de Claude.

65. Statue équestre de Marc-Aurèle,

Figure 7. Rome, Lateran Cathedral and papal palace, groundplan, after Ciampini, De sacris aedificiis, i693. Photo: Bryn Mawr College. 


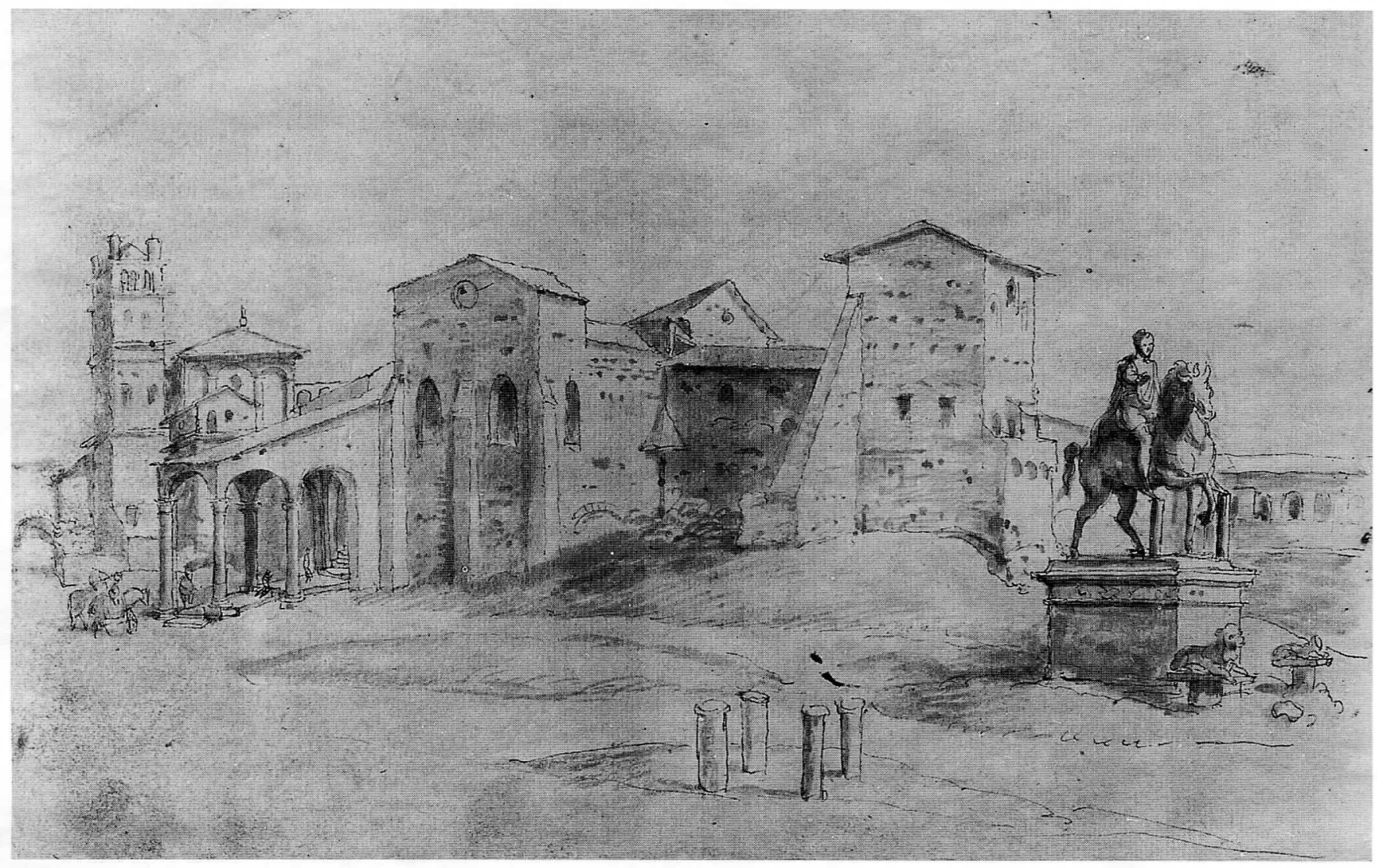

Figure 8. Berlin, Staatliche Museen Preussicher Kulturbesitz, Kupferstichkabinett, 79 D 2, fol. $7 \mathbf{I}^{\mathrm{v}}$, drawing by Maarten van Heemskerck, c. 1535 . Photo: Jörg P. Anders, by permission of the Staatliche Museen.

(figure 7). ${ }^{26}$ The famous view by Maarten van Heemskerck shows it rising on a massive fifteenth-century base in the desolate terrain outside the palace (figure 8). ${ }^{27}$ The rider faces west toward the long-forgotten site of his own ancestral house, the suburban villa of his grandfather Annius Verus, while to his left - behind him in the drawing - once stood barracks of the equites singulares, the cavalry corps that served as the emperor's personal guard. ${ }^{28}$ The barracks were razed shortly after $3^{12}$ to build the cathedral. There are scholars who believe that the statue had stood in approximately the same location since it was first erected in the second century, and others who speculate that it was made for a site in the Roman Forum, or in the precinct of the emperor's triumphal column, or elsewhere, and relocated to the Lateran by Christians. ${ }^{29}$ Ingo Herklotz's argument that the monument was brought to the Lateran plaza in the later part of the eighth century, as part of a grand scheme to collect the surviving bits of ancient Roman Staatssymbolik in order to legitimize new claims to authority by the papacy, has been often repeated and is widely believed.$^{30}$

It must be admitted that the evidence for all opinions concerning the early history of the statue is circumstantial. Its very existence is unverifiable before the tenth century, when it appears in two biographies in the Liber pontificalis, identified as Constantine. At that time it was already in the Campus Lateranensis, where it seems to have functioned as an ensign for what passed for papal justice. ${ }^{31}$ In the life of Pope John xiII (965-972), the pope punishes a treacherous city prefect by hanging the culprit "by the hair of his head on the horse of Constantine as an example to all'. Next we find the body of Boniface, murderer of Pope John xIv (983-984), 'dragged naked by its feet to the Campus, in front of the horse of Constantine, and thrown down and left there'. ${ }^{32}$

It is not easy to imagine how the perfidious prefect was swung from the horse, or from what part of the horse, but that it was possible suggests that the statue was raised at least a few feet above the ground. Comparable monuments in other medieval cities were raised on columns. ${ }^{33}$ Although it has been said that the statue of Marcus Aurelius was displayed the same way, medieval speculations about relatively small details indicate that it must have been much closer to its interpreters, perhaps not as low as it appears in some depictions (figures $9^{-}$II), but plausibly around the height at which it was later displayed by Michelangelo (see figure I). ${ }^{34}$ In I450 Giovanni Rucellai remarked that it was elevated four braccia $(c .2 .2 \mathrm{~m})$, but since he also says that the rider 


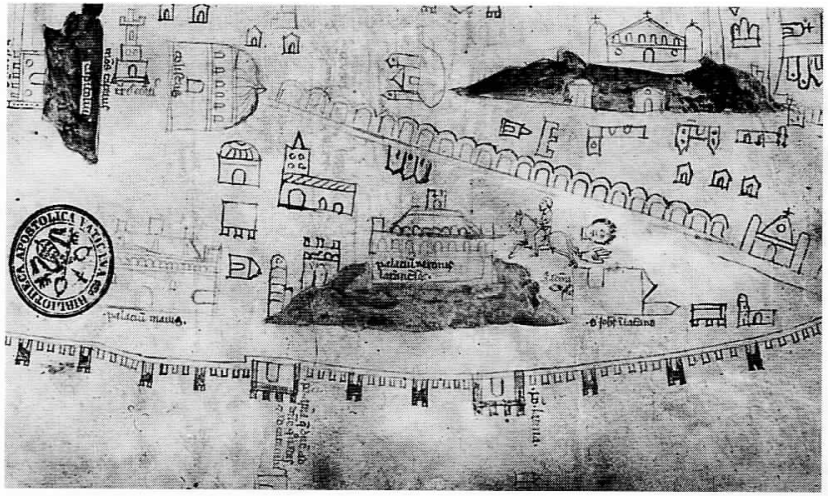

Figure 9. Biblioteca Apostolica Vaticana, Vat. Lat. 196o, fol. $270^{\mathrm{v}}$, map of Rome by Fra Paolino da Venezia, I32I, detail. Photo: Biblioteca Apostolica Vaticana.

was armed, he was not a very reliable observer. ${ }^{35}$ Two years later the imperial emissary Nikolaus Muffel saw the statue 'down on the ground', which has been taken to mean that it had fallen off its support. ${ }^{36}$ That the statue was unstable can be inferred from early fifteenth-century drawings that

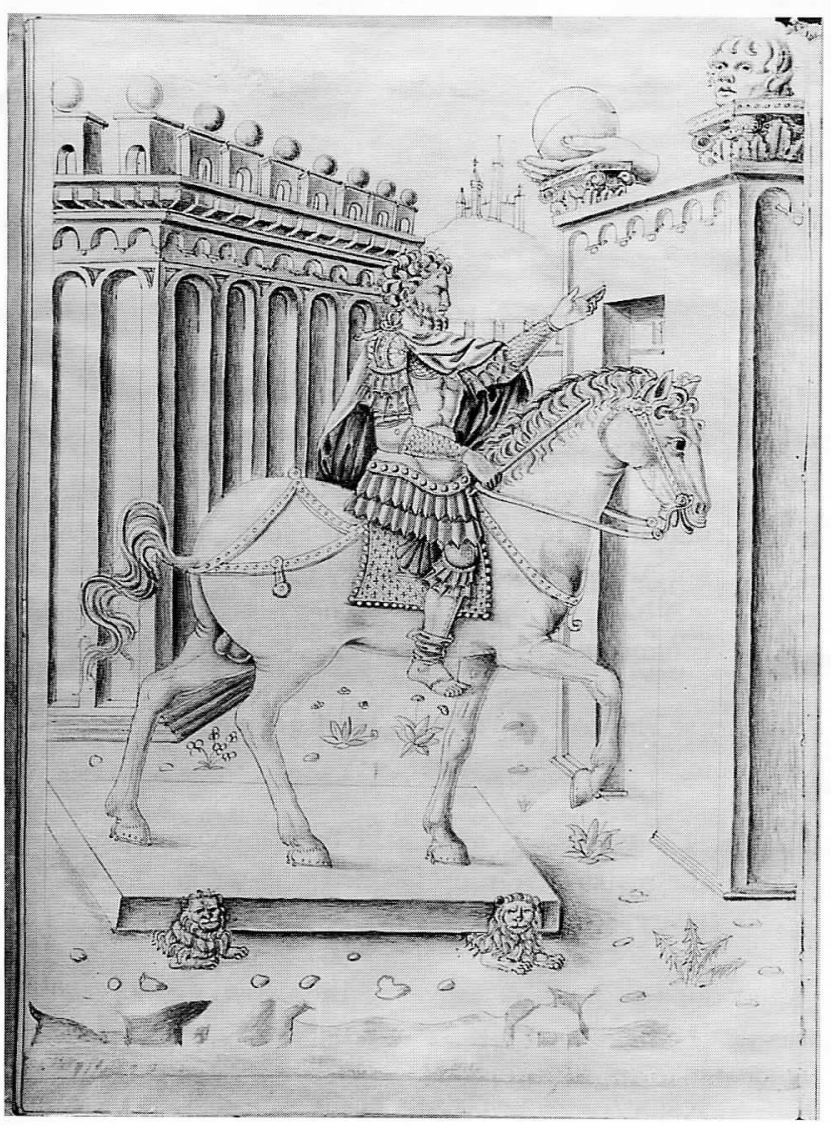

Figure 10. Princeton, University Library, Garrett MS 158, p. xiv, J. Marcanova, Quaedam antiquitatum fragmenta, 1465 . Photo: Princeton University Library. show it anchored on its base by small columns, one or two of which supported the horseman's feet. ${ }^{37}$ The monument was restored several times in the 1460 s and ' 70 , and in 1474 , Pope Sixtus IV re-erected it on the tall, blocky base shown by van Heemskerck and before him by Filippino Lippi (figure 12). ${ }^{38}$ The props are still visible in both of these later views, indicating that the problem of the statue's stability had not been resolved.

The statue's disequilibrium was probably related to the loss or removal of the object that originally supported the horse's right front hoof. Except for this object, the statue must have appeared to medieval spectators much as it did to modern ones until I98I, with the same losses: the reins, which were held in the emperor's left hand (figure i3); the breaststrap (balteus) that connected the edges of the saddle blanket across the horse's chest, keeping the blanket in place; the vertical ornament that was fixed into the horse's bundled forelock (figure I4); and the relief decoration of the phalerae on the bridle. ${ }^{39}$

Like us, medieval viewers saw a colossal rider (double life-size) wearing a short, belted tunic under the paludamentum pinned on his right shoulder. His legs are bare, and he wears the soft, knotted boots of the Roman upper class. He has no weapons or armor, and extends his right arm far from his body as if to display the open hand. The rider sits upon a meticulously rendered saddle blanket with multiple layers, probably of felt, three of which have distinctive ornamental borders generically designated 'Persian'. ${ }^{40}$ There is no saddle in the modern sense nor, of course, are there stirrups.

Unlike us, medieval viewers saw a bent or crouching person under the horse's raised right foreleg. This abject figure features in twelfth- and thirteenth-century descriptions of the statue as well as in some images of 'Constantine of Rome' made by twelfth-century sculptors in France (figures $\left.{ }^{5} 5^{-1} 6\right)^{4{ }^{1}}$ Some modern interpreters have doubted that it was an original feature of the Roman prototype, especially because such a display of subjugation seems incompatible with the clement nature vaunted by Marcus Aurelius' biographers. ${ }^{42}$ But clemency was reserved for worthy foes. According to Cassius Dio, the emperor wished to annihilate the Iazyges, a Sarmatian tribe inhabiting the territory of modern Hungary, because he thought them treacherous, and he so hated Ariogaesus, king of the Quadi, that he offered 500 gold pieces to anyone who could exhibit his severed head. ${ }^{43}$ Helmut Nickel has demonstrated that the 'Persian' saddle blanket was used by nomadic Sarmatians, and he has argued that the saddle cloth as well as the animal wearing it in the statue are Iazygid trophies. ${ }^{44}$ In the presence of such triumphalist details the emblematic captive would not have seemed incongruent, and for this or other reasons most scholars today are inclined to consider it original. It must have been removed sometime before the fifteenth century, when the earliest drawings that can be considered documentary fail to show it. ${ }^{45}$ 


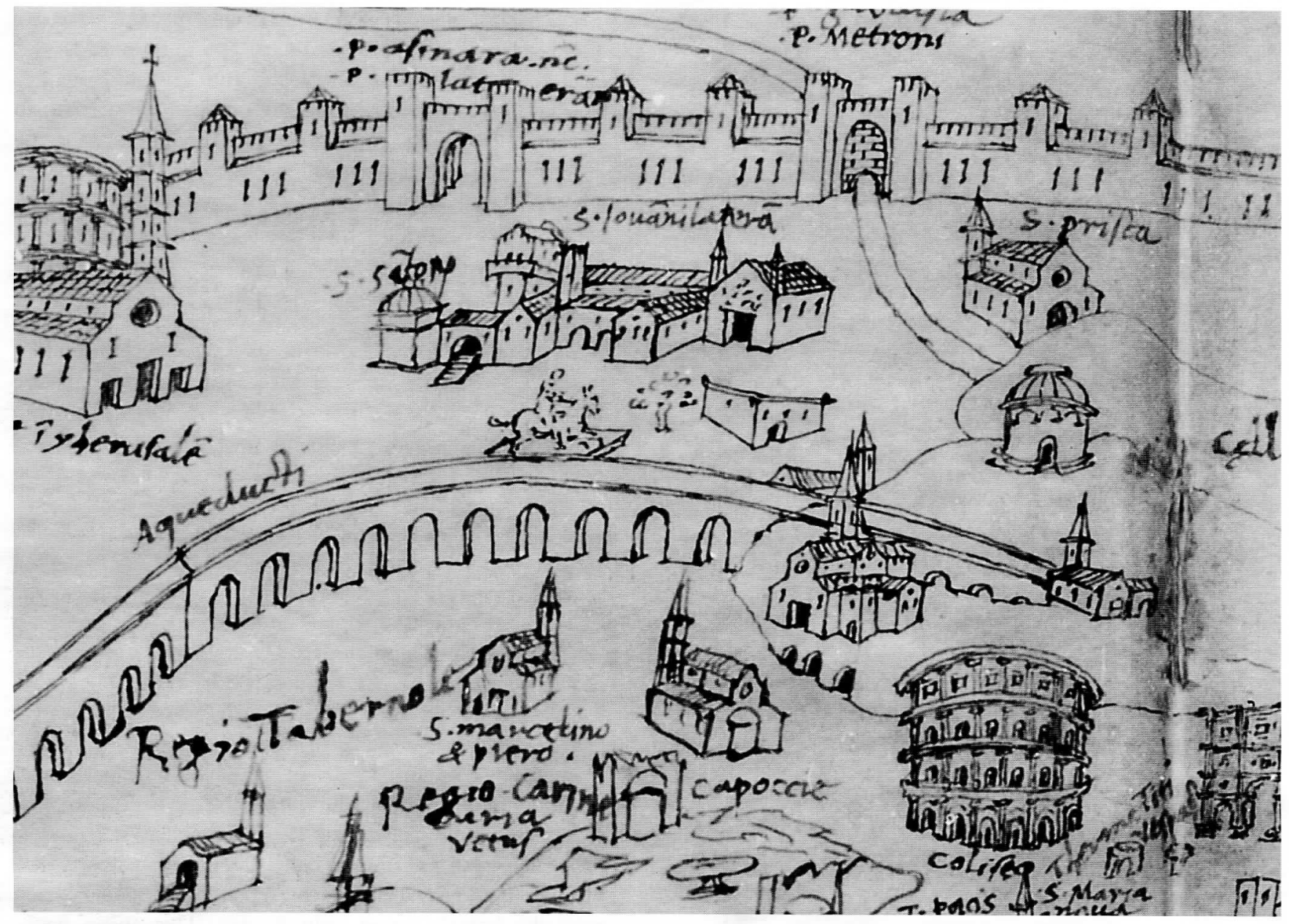

Figure ir. Florence, Biblioteca Laurenziana, Cod. Redi 77, foll. vII ${ }^{\mathrm{v}}-\mathrm{VIII}^{\mathrm{r}}$, map of Rome by Alessandro Strozzi, I474, detail. Photo: Biblioteca Laurenziana.

Several features of the statue, including the symbolic figure under the hoof, recall an infamous precedent, the Equus Domitiani in the Roman Forum (figures $17-18) .{ }^{4}$ Domitian's monument was fulsomely described by Statius in a fawning and bombastic but artfully constructed ekphrasis, which mimics the flickering gaze of a beholder standing in the busy space and sunlight of the Forum, moving distractedly from one feature of the statue to another and sometimes back again before resolving salient details into a whole: ${ }^{47}$

11. I-2 What mighty mass redoubled by the huge form surmounting it stands gathering to itself the Latian forum?

(The statue was colossal.)

11. 5-7 ... have Palladian hands sculpted thee for us, O Germanicus, in such guise as Rhine of late beheld thee reining thy steed, and the astounded Dacian's arduous home?

(It commemorated a military campaign for which Domitian, like Marcus later, earned the title 'Germanicus'.) ll. II-I5 ... This horse would Pergamum [= Troy $]$ ne'er have held, though its wide walls were rent, nor could the mingled throng of lads and unwedded girls have drawn it, nor Aeneas himself nor mighty Hector! That one, besides, was harmful, and contained fierce Achaeans: this one is commended by his gentle rider.

(The horse was too powerful to be restrained by anyone but Domitian.)

11. I5-16 'Tis a pleasure to behold that countenance whereon the marks of war are blended with the guise of tranquil peace.

(The rider's expression conveyed the experience of war, yet was not bellicose.)

11. I8-2I Not more loftily does the Bistonian steed bear Mars when the fighting is done, exulting in the mighty weight, and swiftly flies by the river till he is all asteam and drives Strymon forward with his mighty blowing. 


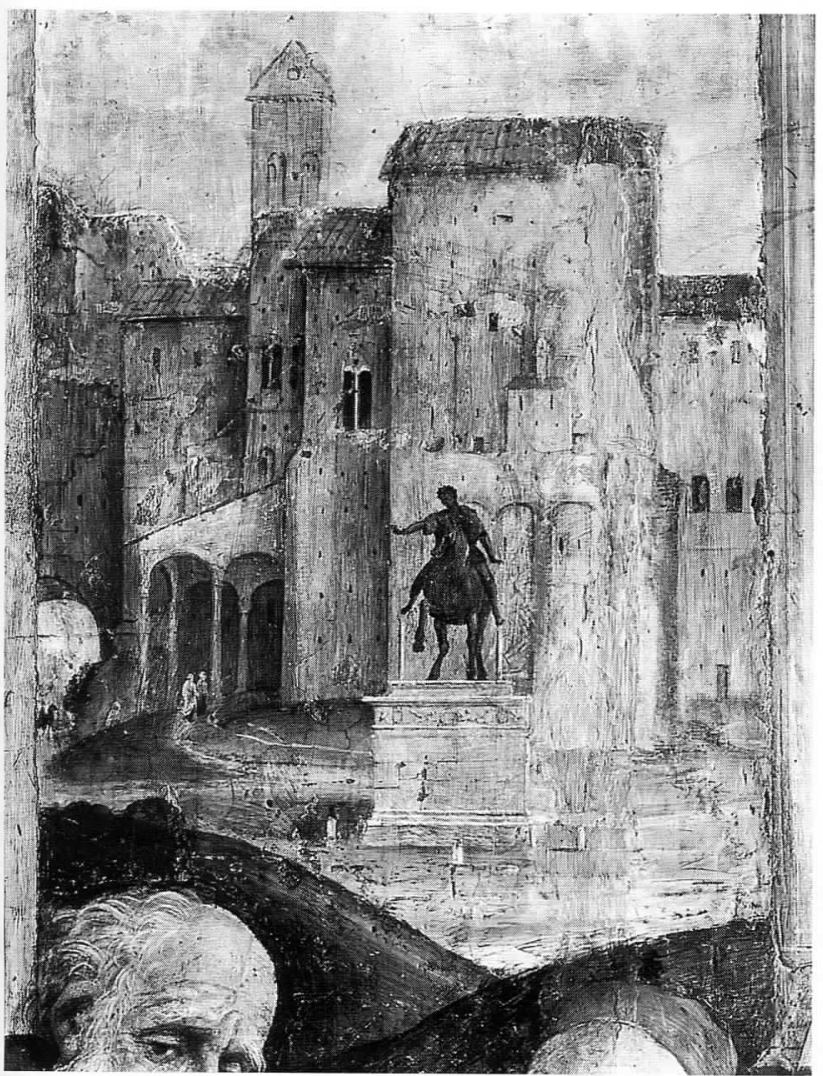

Figure 12. Rome, Santa Maria sopra Minerva, Carafa Chapel, Triumph of St Thomas Aquinas, I488-I493, detail. Photo: Istituto Centrale per il Catalogo e la Documentazione, Neg. E 49325 .

(The horse was of mythical strength and stature.)

II. 29-3I ... Lengthwise thy flanks are guarded, on this hand by the Julian edifice, on that by the high basilica of warlike Paullus; thy back the Sire beholds, and Concord with tranquil brow.

(The monument stood in the Roman Forum with its back to the Temple of Jupiter Capitolinus, between the Basilica Julia to the south and the Basilica Aemilia to the north.)

11. $3^{\mathrm{I}-35}$ Thou thyself with lofty head enshrined in the pure air dost tower resplendent over the temples, and seemest to look forth to see whether the new Palace ... be rising...

(The statue was raised high enough that the rider's gaze seemed to command the whole Forum.)

11. 37-39 ... Thy right hand bids battles cease; thy left the Tritonian maiden [Athena] overburdens not, and holding out Medusa's severed head incites thy steed as with a goad...

(The rider made a pacific gesture with his right hand, and in the left carried a statuette of Athena which itself held the head of the Gorgon.)

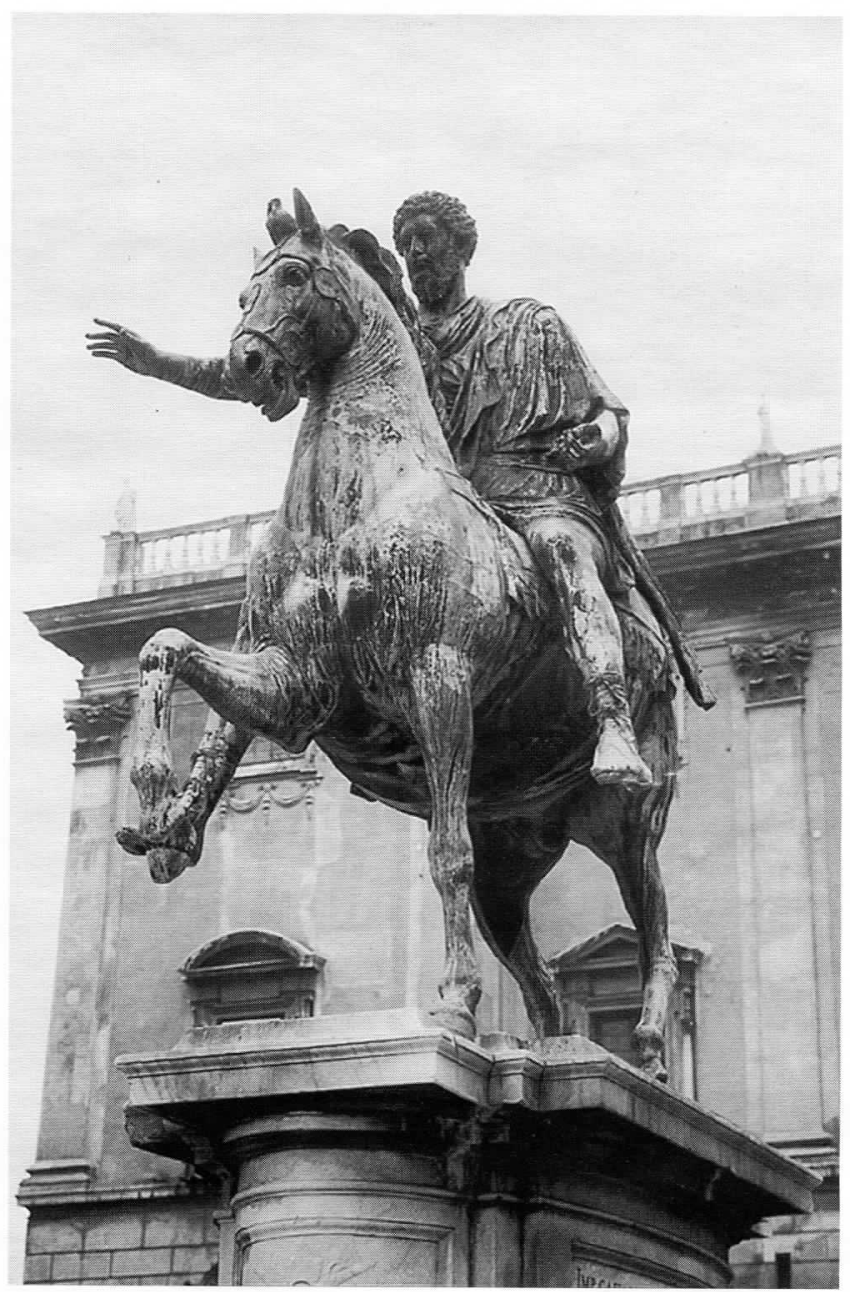

Figure I3. Equestrian statue of Marcus Aurelius from below. Photo: DAI, Neg. 67.652 .

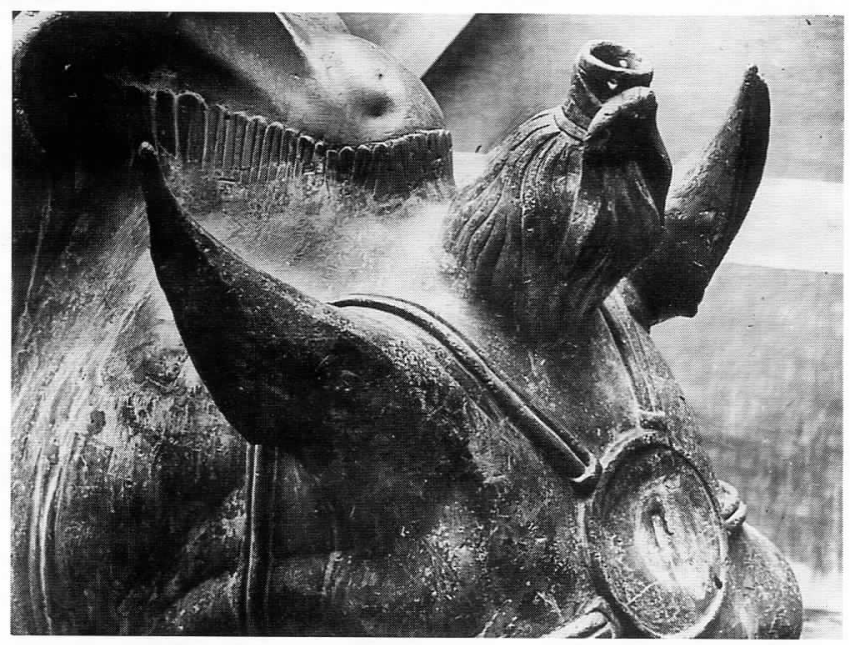

Figure I4. Equestrian statue of Marcus Aurelius, detail of forelock. Photo: DAI, 4I.86I. 


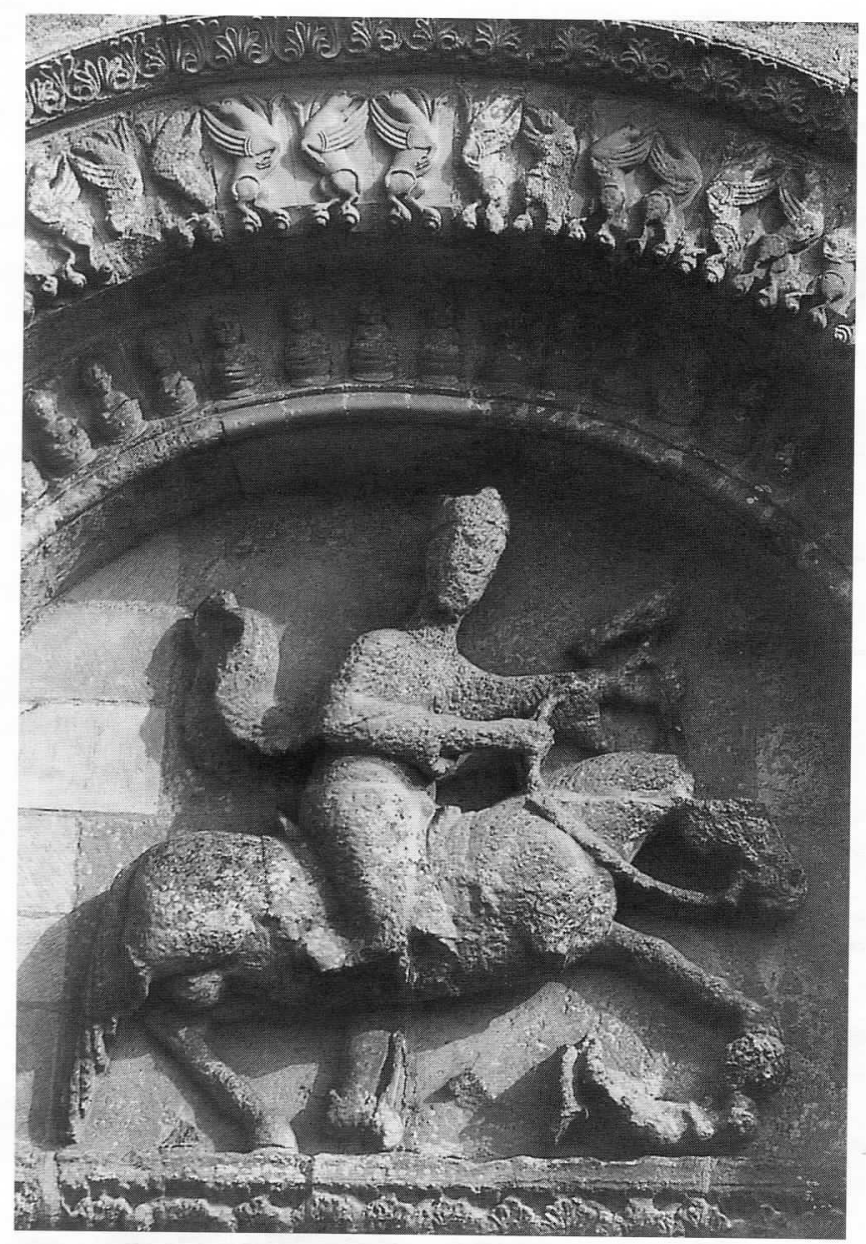

Figure 15. Parthenay-le-Vieux, Saint-Pierre, tympanum, horseman with falcon. Photo: François Bernard.

11. $4 \mathrm{I}-45$ Thy breast is such as might avail to solve the riddles of the universe, and thereon Temese has exhausted the wealth of all her mines; a cloak hangs from thy shoulders; the sword sleeps by thy untroubled side: even so vast a blade does threatening Orion wield on winter nights and terrify the stars.

(He wore a bronze cuirass decorated with allegorical reliefs, and a very large sword hung from his belt.)

11. 46-5o But the steed, counterfeiting the proud mien and spirit of his rider, tosses his head in greater spirit and makes as though to move; the mane stands stiff upon his neck, his shoulders thrill with life, and his flanks spread wide enough for those mighty spurs;

(The horse was more animated than the rider.)

11. $5^{-}-5^{1} \ldots$ in place of a clod of empty earth his brazen hoof tramples the hair of captive Rhine.

(Under the horse's hoof was a river god symbolizing the nation defeated.)

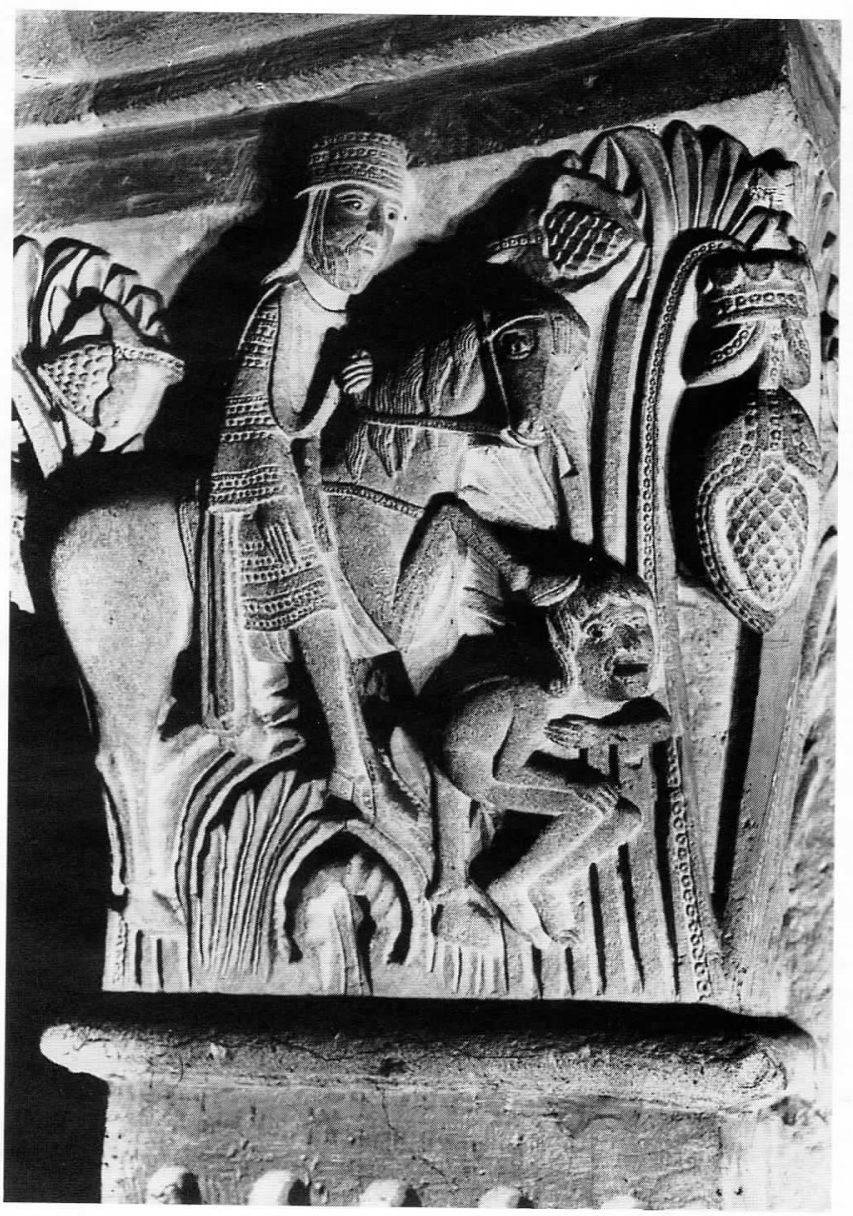

Figure i6. Autun, Saint-Lazare, pier capital, crowned horseman. Photo: CIM, Macon.

1l. 52-58 Seeing him, Adrastus' horse Arion would have been sore afraid, yea Castor's Cyllarus fears as he looks forth upon him from his neighbouring temple. Never will this steed suffer another master's rein. ... Scarce doth the soil hold, and the ground pants beneath the pressure of so vast a weight; and not of iron or bronze: "tis under thy deity it trembles...

(Only this horse, intimidating even to mythical horses, is equal to the divine burden of this rider.)

11. 84-9o Let that steed give place, whose statue stands in Caesar's Forum ... thy daring work, 'tis said, Lysippus, for the Pellaean chief; thereafter on marvelling back he bore the effigy of Caesar.... Who is so boorish as to deny, when he has seen both, that steed differs from steed as ruler from ruler?

(The horse surpassed even the one made by Lysippus in the adjoining Forum of Caesar, which had been set up there as a spoil and given a new Roman portrait.) $)^{4^{8}}$

11. 93-94 This statue ... will stand while earth and sky abide, while Rome's sun endures. 

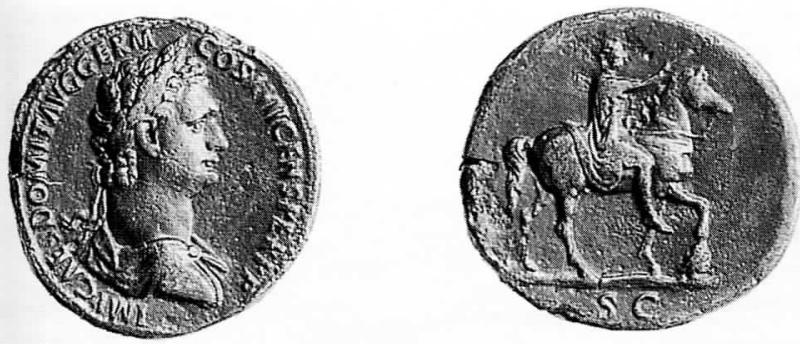

Figure 17. London, British Museum, sestertius of Domitian, 9I CE, obverse and reverse. Photo: (C) copyright the British Museum.
Pessima profezia, remarked Ferdinando Castagnoli, for the statue is generally thought to have been thrown down just five years after it was made, following Domitian's damnatio memoriae in $96 .^{49}$

Medieval readers had virtually no access to this poem..$^{50}$ They could not have used it, as we can, as a lens through which to view an equestrian monument - in many ways like that of Marcus Aurelius - as the intended audience might have seen it. Repeatedly the poem returns attention to the horse, which dominates the cumulative impression; the horse is the chief signifier of the heroism and grandeur of the rider. Meaningful aspects of the rider were the face,



Figure 18. Equestrian statue of Domitian, reconstruction by Luigi Canina, published I845, detail. Photo: Bryn Mawr College. 
the extended right hand, the armor, and the object held in the left hand. The right-hand gesture signaled peace. Marcus Aurelius famously makes the same gesture. His lack of armor disturbs the balance of pacific and bellicose elements, however, and allows the modern viewer, at least, to imagine that his victory was due less to military prowess than to moral superiority. But noble character is portrayed more visibly in the horse. While the rider sits impassive and unmoving, the horse is expressive and restless. Its nostrils flare, its eyes are wide, one ear is pricked (figure I9). Its features and affect resemble Virgil's description of a perfect warhorse: ${ }^{5^{1}}$

From the first, the foal of a noble breed steps higher in the fields and brings down his feet lightly. Boldly he leads the way.... His neck is high, his head clean-cut, his belly short, his back plump, and his gallant chest is rich in muscles.... Should he but hear afar the clash of arms... he pricks up his ears, quivers in his limbs, and snorting rolls beneath his nostrils the gathered fire. His mane is thick and, as he tosses it, falls back on his right shoulder. A double ridge runs along his loins; his hoof scoops out the ground.

The horse is moving more rapidly than a walk, as indicated by the movement of the legs on either side in opposing directions rather than parallel (figures 20-22), but the motion

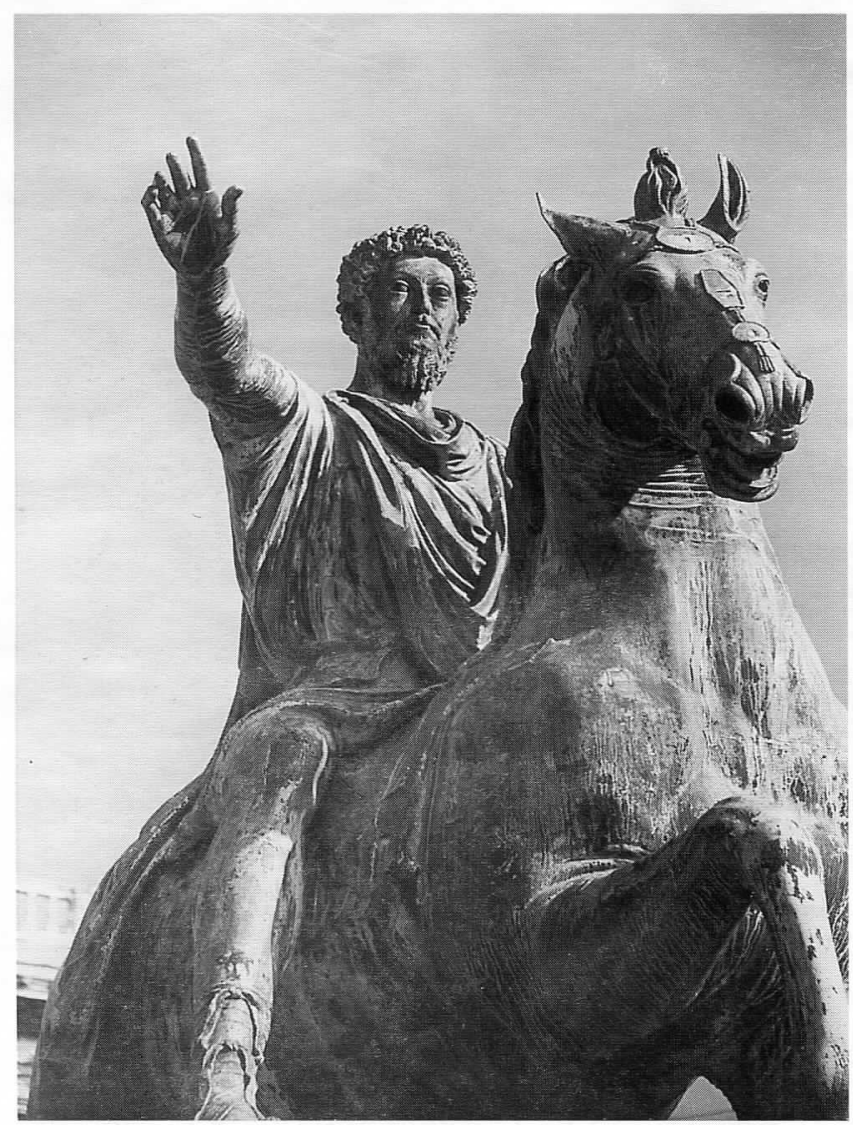

Figure 19. Equestrian statue of Marcus Aurelius, detail. Photo: DAI, Neg. 61.142.

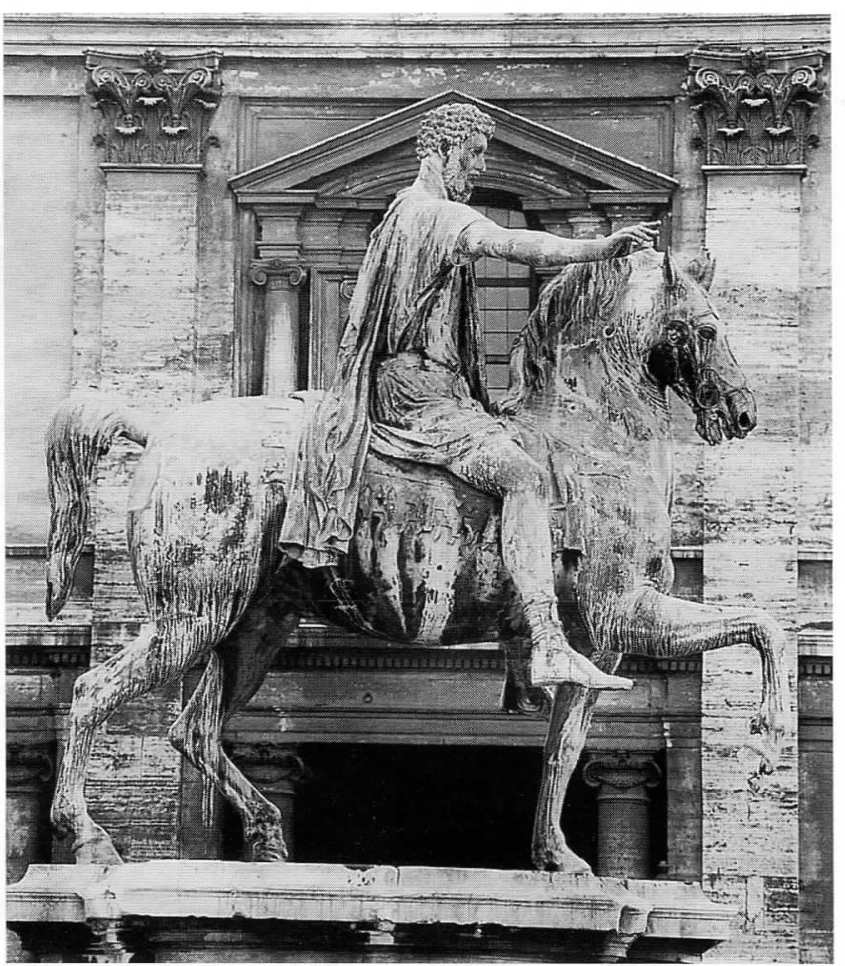

Figure 20. Equestrian Statue of Marcus Aurelius from the side. Photo: DAI, Neg. 72.26 .

is tightly controlled. ${ }^{52}$ The gait has been identified as the collected trot, which bespeaks exacting training and noble aptitude, a horse that is the rider's 'teachable tool'. ${ }^{53}$ This could be the realization of an equestrian ideal, the mount 'only dreamed of' by the Roman cavalry, as one writer opined. ${ }^{54}$ On the other hand, the artisans who recently made its replica were struck by the unusual dentition of the original, which they interpreted as a sign of individuality. ${ }^{55}$ According to this view the horse is a portrait of a particular animal, a position also taken by Nickel because of the Sarmatian saddle. Either way, whether modeled from life or from the collective Roman military imagination, this was no ordinary stallion.

The conceit of the equestrian monument requires that the rider be equal to his horse. Viewers who already know the rider's stature can easily be convinced of this equality, whether or not the sculptor has made it visible. The subjects of Domitian and Marcus Aurelius believed - or knew that they were supposed to believe - that their emperor was omnipotent, and they interpreted images accordingly. The medieval viewers who knew the Lateran statue as Constantine would have made similar assumptions. Constantine was an emperor - even if, in this statue, he did not look like one and the cathedral's founder; his image by definition was one of power. In France, however, twelfth-century representations of 'Constantine of Rome' specified the rider's puissant nature by adding attributes, assimilating him to a contemporary 




Figure 21. 'Clinton' walking, photographs by Eadweard Muybridge, published r887, detail. Photo: Bryn Mawr College.
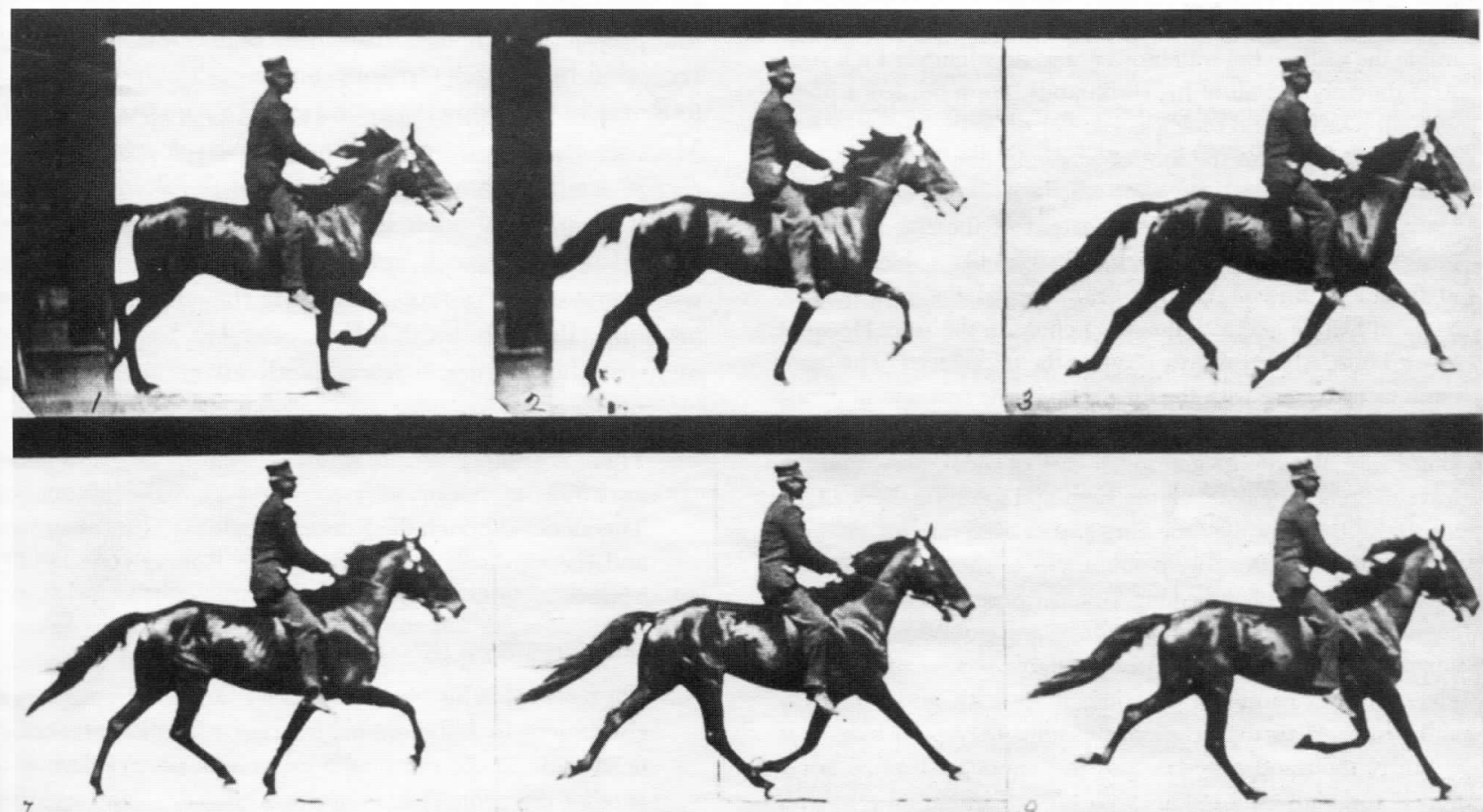

Figure 22. 'Pronto' pacing, photographs by Eadweard Muybridge, published 1887, detail. Photo: Bryn Mawr College. 
action hero (see figures $15-16$ ). ${ }^{56}$ Whether in connection with this development or independently, around the same time the identity of the Roman statue began to be embellished as well.

\section{Argument: '... but it is not so'}

When the Spanish Jew Benjamin of Tudela came to Rome around II6o, his local informants still told him that the horseman at the Lateran was 'Constantinus the Great, who built Constantinople', but by then this was a contentious identification. ${ }^{57}$ Nearly twenty years earlier, the anonymous author of the text known to modern readers as 'Marvels of Rome' (Mirabilia urbis Romae) had published an explanation of the statue which, among other remarkable features, is adamantly non-Constantinian: $:^{8}$

At the Lateran is a certain bronze horse which is called Constantine's, but it is not so; and so anyone who should want to know the truth should read this. In the time of consuls and senators a certain very powerful king came to Italy from the parts of the east; he besieged Rome from the Lateran side; he tormented the Roman people with great slaughter and wars. Then a certain esquire of great physical shape and virtue, courageous and skillful, arose, who said to the consuls and senators: 'If there were someone who would free you from this affliction, what would be the senate's reward?' They said to him in response: 'Whatever he would propose, he would immediately obtain.' He said to them: 'Give me thirty thousand sesterces, and when the war is over you will make for me a memorial of the victory, an excellent horse.' They promised they would do this, just as he had requested. He said: 'Get up in the middle of the night and all arm yourselves and stay inside the walls in the watchtower, and do whatever I tell you.' And they obeyed all of his commands. He mounted a horse without a saddle and took a sickle. For on many nights he had seen that king go to the foot of a certain tree to do his duty, and on his approach an owl, who was sitting in the tree, always sang. Truly that one went out of the city and fixed grass tied up in a bundle, which he carried like a shield-bearer in front of himself. As soon as he heard the owl singing, he went nearer and saw that king come to the tree. He went toward him, who by now was doing the necessaries. The companions who were with the king thought he was one of theirs; they began to shout that he should take himself out of the king's way. But not giving up because of them, pretending to leave the place, he reached the king, and scorning them all, by his strength he grabbed the king and carried him off. As soon as he reached the city walls, he began to shout: 'Go out and kill the entire army of the king, because here I am holding him captive.' Going out they killed some, and put others to flight; whence the Romans got an incalculable weight of gold and silver. So they came back glorious to the city, and what they had promised to that aforesaid esquire they paid him, that is, thirty thousand sesterces and in memory a bronze horse gilded and without a saddle, with himself sitting on top, with the right hand extended with which he had caught the king; on the head of the horse a memorial of the bird, by whose song he obtained the victory; under the hoof of the horse he fixed in memory that very king, who had been of small stature, with his hands tied behind his back, just as he had caught him.

The Mirabilia urbis Romae is an eclectic compilation that attempts to resurrect pre-Christian Rome for medieval readers. It contains a few other long narrative chapters like this one, but its principal content is an enumeration of Rome's ancient buildings, topographically arranged as if in a guidebook. Its date of composition coincides with the revival of the Roman senate in I I43, the defining, though far from final event in a long struggle for control of Rome among papal, imperial, and citizens' factions. Given the chronological coincidence, it has seemed natural since the nineteenth century - when religious and secular factions were again in battle over Rome - to view the Mirabilia as a partisan political document. ${ }^{59}$ Reading the chapter on the equestrian statue in this light, Ingo Herklotz and Norberto Gramaccini have argued that the intention of the Mirabilia's revisionist interpretation was to replace a pro-papal symbol (Constantine, author of the 'Donation' that legitimized the popes' secular dominion) with a populist, pro-senatorial one, the 'knightly hero'. ${ }^{60}$ Chiara Frugoni has taken an opposing stance, proposing that the displacement of Constantine by a lowly armige was the work of papal rather than senatorial propagandists; but she equally ascribes the origin of the story to a tendentious political agenda. ${ }^{6 \text { I }}$

Whether or not it is correct, the political interpretation does not account for the story's weirder details, the owl and the defecating king, nor for its narrative form. The method that produced these features can be deduced from the story' reception by Master Gregory, an Englishman who traveled to Rome in the following century. Gregory's 'Account of the Marvels of the City of Rome' (Narracio de mirabilibus urbi Romae) seems to have been written in the decade $1226-36$, and it clearly embodies first-hand observation. ${ }^{62}$ Although he had not necessarily read the Mirabilia, he was familiar with some of its contents, including the story of the armiger probably through local informants. He begins his treatment of the 'immense horse' with an enumeration of it interpreters: ${ }^{63}$

There is another bronze statue in front of the papal palace: an immense horse, with a rider whom the pilgrims call Theoderic, although the Roman people say he is Constantine, and the cardinals and clerks of the Roman curia call him Marcus or Quintus Quirinus.

He then provides a description:

The rider raises his right hand, as if to address the people or to give orders; his left hand holds a rein, which turns the horse's head aside to the right, as if he were about to ride away in another direction. A little bird, which they call a cuckoo, sits between the ears of the horse, and under the hoofs there is a sort of dwarf, who is being trodden upon. He makes a wonderful image of the agonies of death. 
Evidently, the statue was an object of oral disputation among three interpretive communities: pilgrims, the local populus, and the clergy. ${ }^{64}$ The populace conservatively maintained the identification passed down from at least the tenth century. The pilgrims cast the rider in their own image, as a foreigner. ${ }^{6}$ The clergy - presumably the only predominantly literate community of the three - proposed two different discursive interpretations. The first, in which the rider, remarkably, is called Marcus, is a close variant of the Mirabilia's story of the armiger. ${ }^{66}$ The second interpretation identifies the statue with a classical exemplum virtutis, the Republican hero known to Livy as Marcus Curtius, but called Quintus Quirinus by Gregory. A conspicuous difference between these two narratives is that the first, Mirabilia-like tale accounts for the details pointed out in Gregory's description of the statue, and the second, Livian one does not. ${ }^{67}$ In retrospect it is easy to see that the ad hoc story of the armiger is what has been called a 'novelistic etiology', an explanation that generates narrative to rationalize enigmatic details. ${ }^{68}$ The story of Quintus Quirinus (Marcus Curtius), by contrast, is a literate attempt to match an ancient Roman artifact with an already existing ancient text. Its method is close to that used by art historians today.

I think it likely that the etiological narrative of the armiger originated in oral conjecture years or decades before it was codified for literates in the Mirabilia urbis Romae around II43. ${ }^{69}$ It is explicable as the product of visual examination, recreated by Master Gregory as description, and inferential narrative elaboration. One can imagination a community of interpreters scrutinizing the statue's peculiarities, questioning their meaning or rationale, and trading answers until a set that seemed cogent or plausible was achieved. This would not have been a peculiarly medieval approach to the decipherment of public iconography. A mode of interrogatory spectatorship is reflected in literary sources as old as the fifth century BCE, and the same mode or something like it probably is employed by all audiences for public imagery whenever signifiers fail to evoke expected or obvious signifieds. ${ }^{70}$ The tenth-century Byzantine collection of ancient verses known as the Greek Anthology preserves several hellenistic epigrams that model an interrogatory approach to deciphering the emblems on funerary stelai, sometimes in the form of dialogic voices: ${ }^{71}$

A: I seek to discover what the meaning of these carvings is that Agis made upon your stele, Lysidice. For the reins and muzzle and the bird who comes from Tanagra celebrated for its fowls, the bold awaker of battles, such are not things that please or become sedentary women, but rather the works of the spindle and the loom.

$\mathrm{B}$ : The bird of the night proclaims me one who rises in the night to work, the reins tell that I directed my house, and this horse's muzzle that I was not fond of many words and talkative, but full of admirable silence.
An epigram on deciphering the stele of Antipater of Sidon comes very close to what I imagine occurring among medieval interpreters of the Lateran horse, a casually methodical process of trial and error: ${ }^{72}$

Tell me, thou stone, why does this bright-eyed cock stand on thee as an emblem, bearing a sceptre in his lustred wing and seizing in his claws the branch of victory, while cast at the very edge of the base lies a die? Dost thou ever cover some sceptred king victorious in battle? But why the die thy plaything? And besides, why is the tomb so simple? It would suit a poor man woke up o'nights by the crowing of the cock. But I don't think that is right, for the sceptre tells against it. Then you cover an athlete, a winner in the foot-race? No, I don't hit it off so either, for what resemblance does a swift-footed man bear to a die? Now I have it: the palm does not mean victory, but prolific Tyre, the proud mother of palms, was the dead man's birthplace; the cock signifies that he was a man who made himself heard, a champion too I suppose in love matters and a versatile songster. The sceptre he holds is emblematic of his speech and the die cast wide means that in his cups he fell and died. Well, these are symbols, but the stone tells us his name, Antipater, descended from most puissant ancestors.

Among the several resemblances to the heuristic approach revealed in the medieval story of the armiger is a willingness to admit ignoble details: for all his poetic achievement, Antipater died by falling down drunk.

I do not mean to suggest that the Mirabilia urbis Romae perpetuates or revives a literary tradition going back to ancient Greece; on the contrary. I am proposing that the Mirabilia captures for its own purposes - whatever they may have been - a timeless mode of deciphering signs displayed in public that is common to many cultures and conducted on all levels, from the oral culture of the street to clite literature. Its method assumes that - precisely because they are public - apparently empty signs are meaningful, and can be made so by matching signifiers with culturally or communally plausible signifieds.

For medieval viewers of the Lateran equestrian statue, its initial failure to communicate must have stemmed principally from the discrepancy that also affects the response of modern viewers: the visible inequality of rider and mount. Whereas we might perceive the incongruence in terms of expressivity or physical vitality, medievals would have attended to more concrete attributes. The rider had no armor, so he could not be a warrior or knight, and he has none of the insignia of a king, much less an emperor. His garments seemed exiguous. The Roman de Rou by the Norman poet Wace, written around the time of Benjamin of Tudela, may play on this last perception in a passage in which the eleventh-century hero Robert Guiscard encounters the statue of 'Constantine' exposed to wind and rain, and displays his knightly courtesy by giving the bronze figure something to wear, 'the finest mantle he could find'. ${ }^{73}$ 
It was a puzzle that this inadequately outfitted rider should be commemorated on a great horse. The horse's signifying power is all but lost today, when only certain athletes and hobbyists are equestrians. The rest of us ride in cars, and the automobile has appropriated the symbolic functions invested by pre-industrial cultures in other means of transport. Unlike us, nearly every ancient and medieval viewer would have brought some degree of horse lore to this statue. Traces of the ancient Roman knowledge can be found in Virgil on the warhorse, already quoted, and in Varro's note that horses are of several functional types: ${ }^{74}$

As some horses are fitted for military service, others for hauling, others for breeding, and others for racing, all are not to be judged and valued by the same standards. Thus the experienced soldier chooses his horses by one standard and feeds and trains them in one way, and the charioteer and circus-rider in another; ... in the army, they want spirited horses, ... on the other hand they prefer more docile ones for road service.

For all of these types of horses Varro used one word, equus, modified by appropriate adjectives and phrases. The Middle Ages developed a much more differentiated equine vocabulary, exemplified by Albertus Magnus around i26o: ${ }^{75}$

In our part of the world four types of domesticated horses are recognized: war horses or chargers [dextrarii]; palfreys [palefridi]; race horses [curriles equi]; and plow horses [runcini].

Albert's 'part of the world' was Germany, where he wrote De animalibus, but dextrarii, palefridi, and runcini were standard terms throughout feudal Europe. These functional distinctions among equines were correlated with peculiarly medieval classifications of people, exemplified by the canonical three orders: knights, priests, and laborers. Horses became social signifiers, indicative of the rank or situation of their riders. In art as in life, the 'great horse,' the dextrarius or destrier, was the sole prerogative of the knight, and then only in battle. ${ }^{76}$ The palfrey was the mount of high-status women and of clerics. The runcinus, roncin or rouncey was a workhorse; it could be ridden, but it was mortifying for a knight to have to do so. In the heavily coded culture of chivalry, verbal and visible distinctions among horses constituted a prominent semiotic field. The signs corresponded to real-life developments in warfare and equine genetics, as ever-larger and more powerful dextrarii were bred to carry the ever greater weight of metal-clad knights. ${ }^{77}$

Although it might have been on the small side for a medieval warrior, the horse of Marcus Aurelius was perceived as large (equus inmensus) and valorous (optimus equus) a destrier - by its medieval observers. Presumably they were convinced of this stature by other features. The horse exhibits many of the traits later identified by Albertus Magnus as signs of good form and beauty: ${ }^{78}$
Good form is exhibited when the body is powerful and robust; ... the flanks are long; the rumps are well-rounded; the entire body ripples with firmly knotted muscles; the legs are strong, sleek and uniform in circumference from knee to foot...

A horse has beauty when its head is relatively small in comparison to the body...; the eyes are large and seemingly project from the front of the head; the ears are short, pointed and directed forward; it has wide nostrils which it plunges deeply into water when it drinks; it has a straight, erect neck, a thick mane, a long, full tail, and an amply rounded body marked by a firm stance.

The interpretation recounted in the Mirabilia urbis Romae explains the discrepancy between the fine bronze horse and its less distinguished rider by calling the latter an armiger or squire, a knight's assistant. In its strict sense 'armiger' denoted a member of the warrior class who, because of lack of resources or of seniority, was not entitled to have a great horse. ${ }^{79}$ The armiger might lead such a horse for its knightly rider (figure 23), or care for it while its owner did not need it. ${ }^{80}$ A capital in the cloister of Sant'Orso in Aosta, not far in date from the Mirabilia urbis Romae, shows St Ursus rescuing a young armiger (ARMIGER ERRANS) who, thinking that he had lost his master's best horse, was 'frightened to death' (figure 24). ${ }^{81}$

Medieval interpreters of the Roman statue must have assumed that it encrypted the story of how an armiger came to be portrayed on the horse of a knight. The clues to be decoded included the strange shape between the horse's ears - which, viewed from a certain angle (figure 25), does look bird-like — , the display of the rider's empty hand, and the trampled enemy. The latter presumably resembled the barbarian foes shown on Antonine reliefs, shaggy men partially clothed in pajama-like trousers (see figure 5) or naked but for their open mantles and torques. The kneeling figure at the corner of a fragmentary sarcophagus, his chin crushed to his knee under the feet of a tripping Victory, may be the marble counterpart of the bronze 'king ... of small stature, with his hands tied behind his back' seen by medievals trapped by the hoof of the armiger's horse (figure 26). ${ }^{82}$

An enemy in a state of undress, evidently subdued without the aid of weapons, could have been caught in a compromising situation: sex or at the toilet. The owl-like bird was a sign that the event happened at night; this might favor sex, but there was no visible partner. That left bodily elimination. Unquestionably it is a moment of vulnerability. According to the biography in the Historia Augusta, Caracalla was assassinated when he dismounted from his horse to pee. ${ }^{8}$ More pertinent here, King Saul was almost done in by David when he went into a cave where David was hiding to relieve himself (figure 27). ${ }^{8}{ }^{4}$ David crept close enough to cut off a piece of Saul's garment, but stopped short of killing 


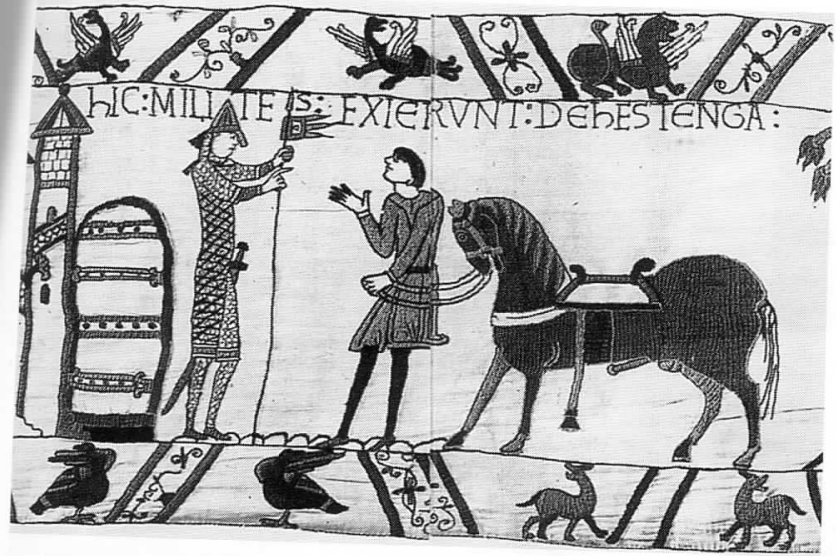

Figure 23. Bayeux Tapestry, after I066, detail. Photo: after Édition Ville de Bayeux.

him when he was overwhelmed by doubt that the Lord would approve.

The detail of the king caught with his pants down was not necessarily inspired by the story of King Saul, but the tale of the armiger does have a Biblical cast. The hero who wins by cunning, trickery, or duplicity is an Old Testament type (Jacob); and the weaponless hero who defeats a seemingly invincible enemy clearly recalls David and Goliath, although the antagonists' physical characteristics are inverted. ${ }^{85}$ In the only other chapter in the Mirabilia urbis Romae that explicates an extant antique statue, the Bible is invoked directly. This chapter concerns the marble Horse Tamers on the Quirinal Hill (figures 28-29), and it purports to explain 'for what reason [the horses] have been made naked, and the men naked, and what they are counting.... ${ }^{86}$ The premise of the exposition is the same as that applied to the 'horse of Constantine': the statues commemorate an extraordinary deed by an unlikely hero (in this case, 'two young philosophers,

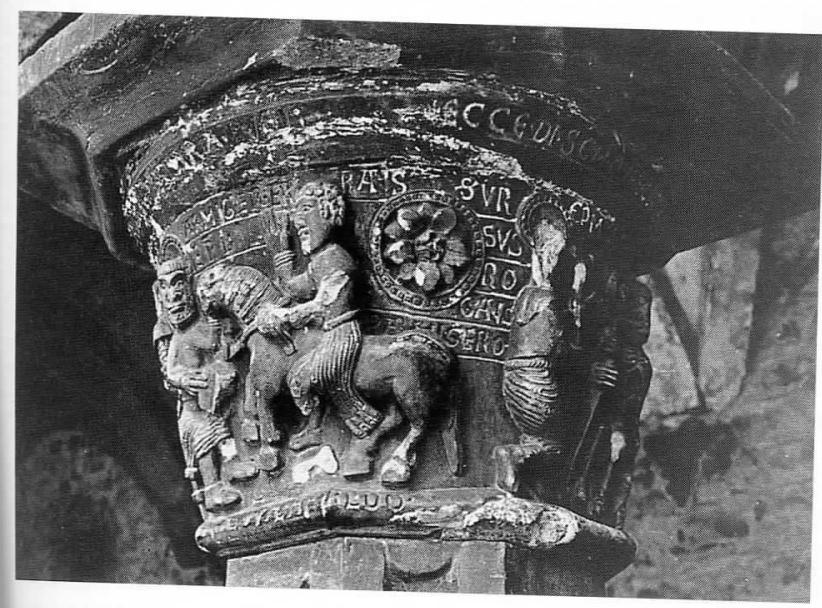

Figure 24. Aosta, Cloister of Sant'Orso, I2th century, capital. Photo: SACAT, Turin.

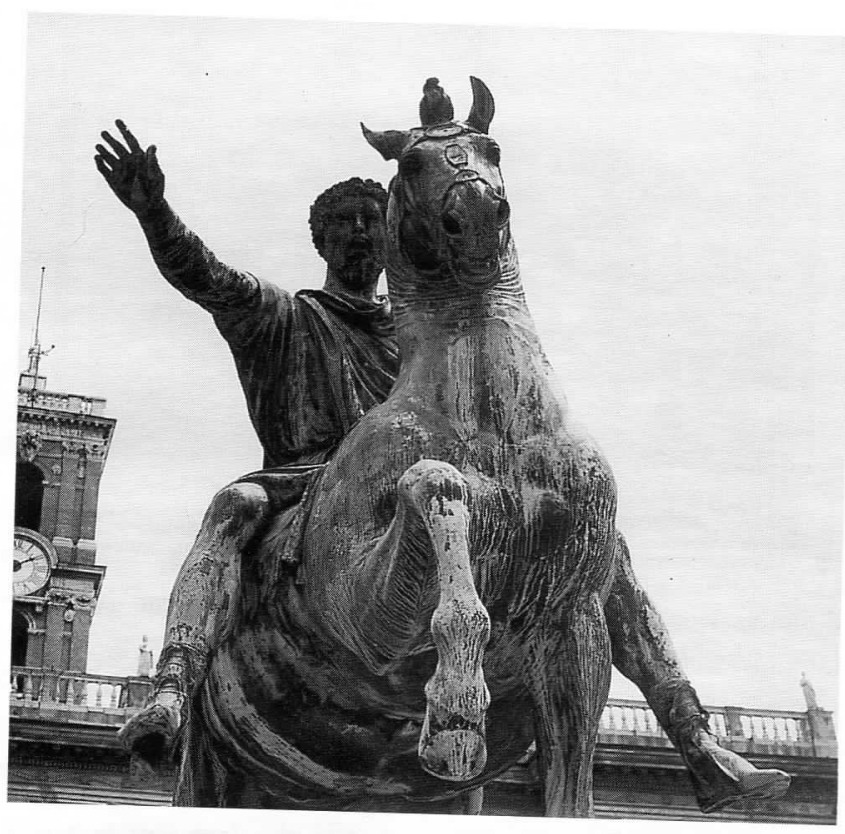

Figure 25. Equestrian statue of Marcus Aurelius from below. Photo: DAI Neg. 69.2362 .

Praxiteles and Phidias'). Again the heroes are allowed to name the reward for their achievement, and again they choose a statuary monument. In this story, however, the features of the monument are assigned allegorical meanings; the horses represent 'the powerful princes of this world, who rule over the men of this earth. A most powerful king will come who will mount upon the horses, that is upon the power of the princes of this world.' The 'semi-naked' young men, with their 'raised arms and bent fingers, are counting

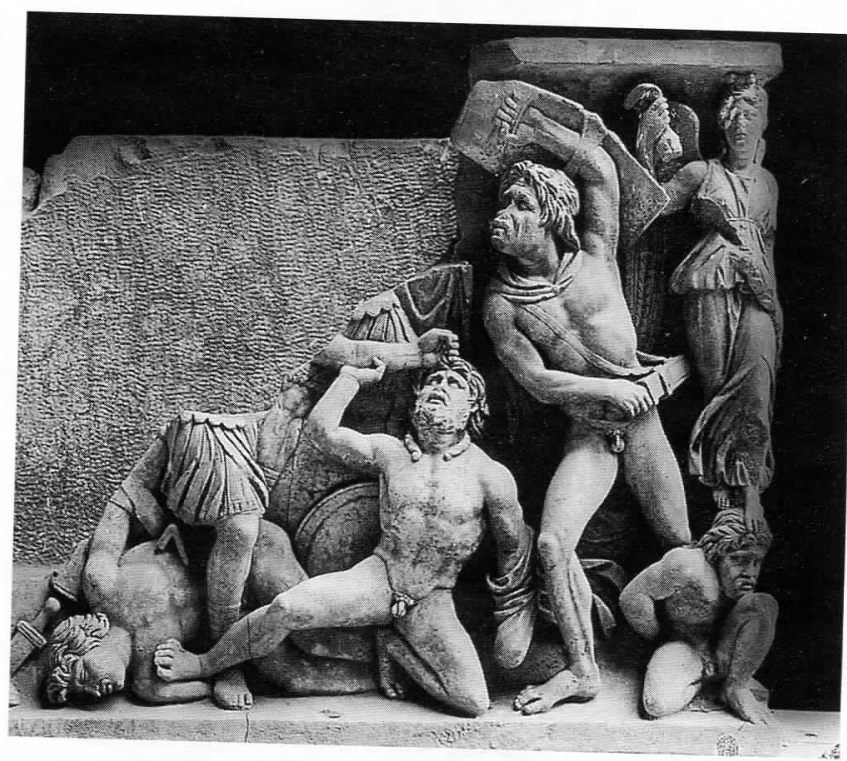

Figure 26. Rome, Museo Nazionale delle Terme, sarcophagus no. I08437, c. $170-80$, detail. Photo: DAI, Neg. 7I 48 . 


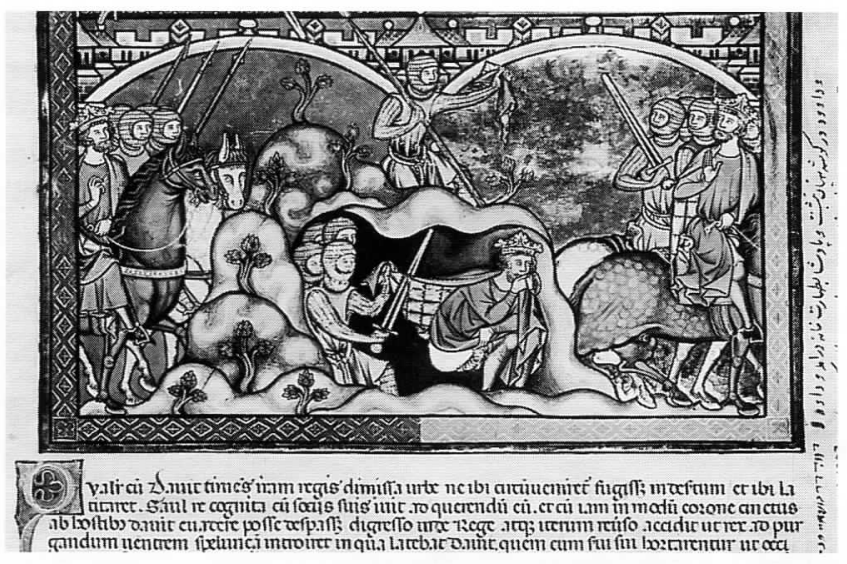

Figure 27. New York, Pierpont Morgan Library, M. 638, fol. 33, detail. Photo: Morgan Library.

those [years?] which are to come. And just as they are naked, so all worldly knowledge is naked and open to their minds.' Erwin Panofsky noticed that the last words are a close paraphrase of the Epistle to the Hebrews: 'And no creature is invisible in [God's] sight; everything is naked and open to his eyes'. ${ }^{87}$

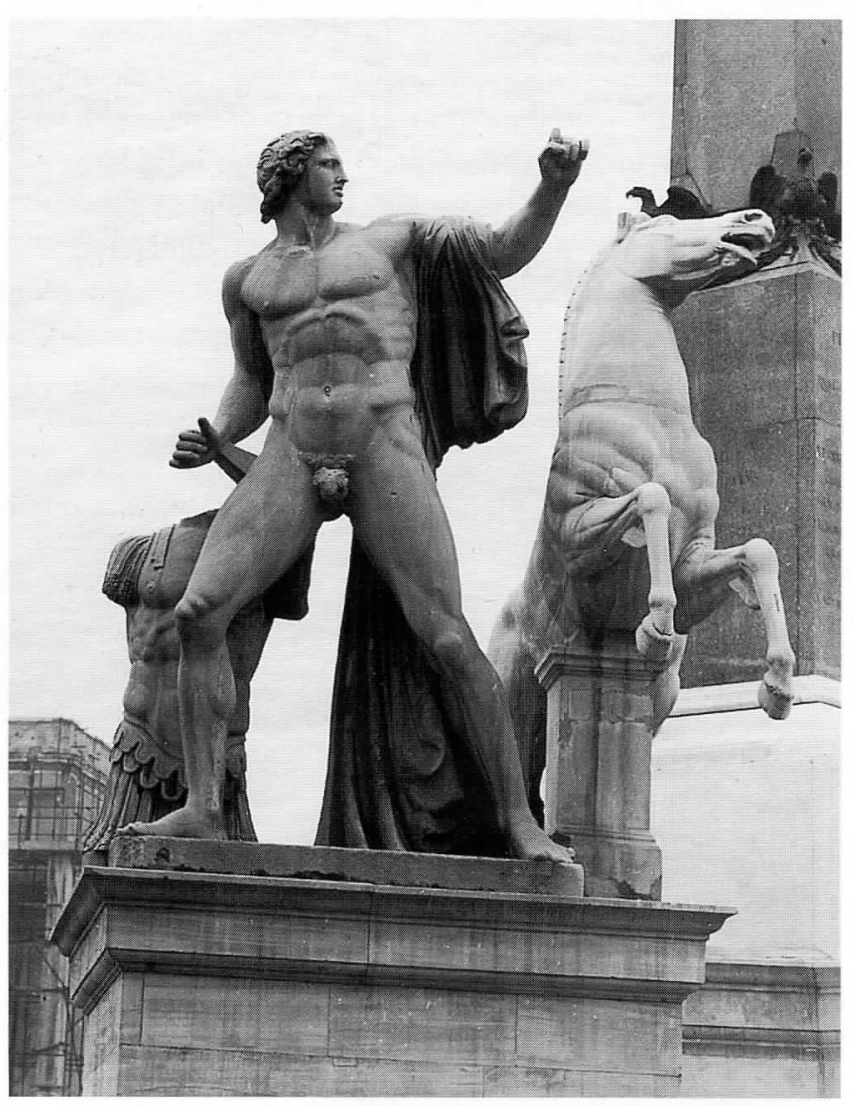

Figure 28. Rome, Quirinal Hill, Horse Tamer, 'opus Fidiae'. Photo: DAI, 75.594.

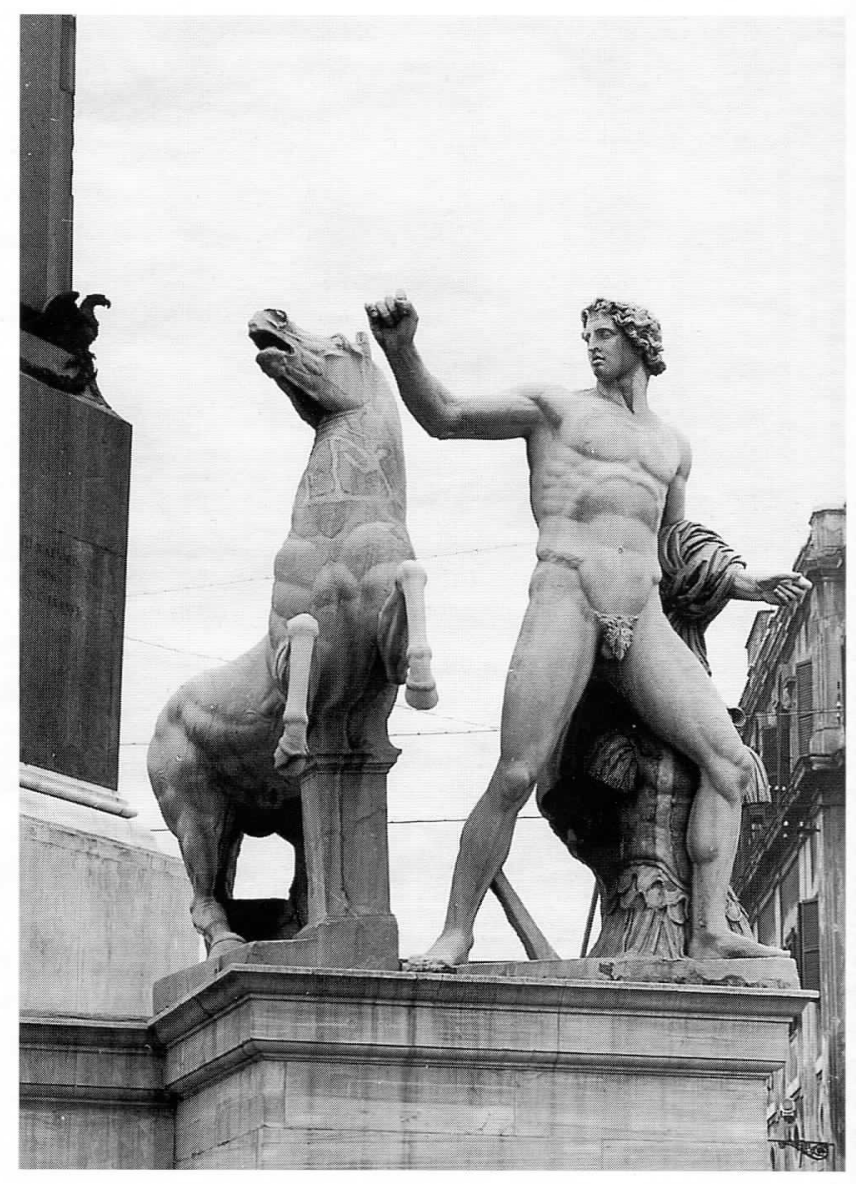

Figure 29. Rome, Quirinal Hill, Horse Tamer, 'opus Praxitelis'. Photo: DAI, Neg. $75 \cdot 589$.

Andreas Thielemann's brilliant analysis of the story of the Horse Tamers reveals a composition similar to that posited here for the bronze equestrian statue: a narrative constructed on the foundation of anomalous details, which are laid out 'like a riddle' for solution. ${ }^{88}$ Like most recent interpreters of the Mirabilia urbis Romae, Thielemann is guided by the nineteenth-century assumption that it was a deliberately political document - he identifies its Tendenz as prosenate - and consequently he reads its interpretation of the Horse Tamers as an allegory of current events. The king who will come to harness the unbridled power of the horses is Conrad III (II $\left.3^{8-} \mathrm{II} 5^{2}\right)$, or for later readers Frederick Barbarossa (II52-IIgo), or for the original audience, Henry Iv (I056-I I06). Thielemann proposes that the story was authored by Benzo of Alba (d. I089/9o), which makes the anonymous compiler of the Mirabilia a later 'editor' with, evidently, the same political outlook as the author.

It is not necessary to concur in Thielemann's interpretation of the allegory to agree that the allegorical mode distinguishes the story of the Horse Tamers fundamentally from that of the Lateran rider. The cue to medieval viewers to search for another level of meaning in the Horse Tamers 
seems to have been the nudity of the heroes, although as Thielemann demonstrates, the crux of the allegory was found in the nudity of the horses, that is, the lack of reins. ${ }^{89}$ The equestrian statue, by contrast, was read as history, although the understanding of history was sui generis, unlike ours or even Master Gregory's a century later. History was a fairy-tale realm of incalculable antiquity ("the time of consuls and senators'). It was not fixed in any text, but was embedded in the relics and debris of Roman topography. History was whatever story the monuments might choose to tell. Master Gregory approached the city differently, with a history preconstructed from his reading: principally Lucan and Virgil, the same texts we use today. As mentioned earlier, his learned identification of the statue of Marcus Aurelius came from Livy, albeit probably through oral intermediaries.

In its treatment of history the Mirabilia resembles the Gesta Romanorum, a body of tales with Christian moralizations that circulated in England and Germany from at least the thirteenth century..$^{90}$ The stories of the Gesta Romanorum show the same anachronistic mix of Roman and feudal features. They open similarly with scene-setting allusions to the ancient past, often naming real historical figures ('there was a certain very old prince of the Romans named Pompey') or, as in the Mirabilia, an office ('There was a certain emperor...'). ${ }^{9 \text { I }}$ Supernatural events are commonplace. Diction and style are colloquial, and action is frequently replaced by quoted or indirect dialogue among the characters. ${ }^{92}$ One of the tales even follows the same pattern as the armiger's, at least initially: a domain (the property of a noble lady) is ravaged by a tyrant. Seeing her helpless, an unlikely hero (a pilgrim) volunteers to drive off the tyrant in exchange for a memorial of himself. The hero defeats the villain; but then the tale takes a different course. The hero himself is slain, and the lady, after making the memorial as he requested, fails to preserve it. The moral is drawn as follows: ${ }^{93}$

...The lady is the human soul, and the tyrant is the devil, who spoils us of our heavenly inheritance. The pilgrim is Christ, who fights for and redeems us; but, forgetful of His services, we receive the devil, the world, and the flesh, into the chamber of our souls, and put away the memorials of our Saviour's love.

It is not impossible that the Mirabilia's stories also had an edifying and/or homiletic use. ${ }^{94}$

Created in or formatted for a popular milieu, the tales of the Mirabilia urbis Romae and the Gesta Romanorum freely combine elements of literature, folklore, and daily life. The difference between them and Master Gregory's interpretation is a matter of intellectual formation. Master Gregory was, if not a protohumanist, at least prehumanist. His alienation from the culture of novelistic etiology may be reflected in the fact that his retelling of the tale of the armiger is less satisfying than the version transcribed in the Mirabilia urbis Romae. In
Master Gregory's words the squire becomes a knight (miles), which subverts the tale's relation to the statue; and the owl, to no particularly good effect (except that it makes a much better title for this essay), becomes a cuckoo. The king's need to relieve himself is replaced by a more decorous motive, the desire to practice his magic. ${ }^{95}$

The twelfth- and thirteenth-century debate about the statue had no definitive issue, and fourteenth-century sources show confusion. Romans continued to call it 'Constantine', as indicated by accounts of the festival staged in 1347 to celebrate the knighting of Cola di Rienzo, which featured the equus Domini Constantini decked out in fur and spouting wine and water from its nostrils. ${ }^{96}$ Readers of the Mirabilia tried to avoid the discredited old name, even if they had no better alternative. The mid-century poem Dittamondo by the Tuscan author Fazio degli Uberti calls the bronze horseman 'Big Curly': 97

Quel gran ricciuto appresso al Laterano,
Ch'uom dice Costantin, ma quel non fue.

'Ricciuto' did not catch on, but another fourteenth-century nickname, Gran Villano (Big Peasant), stuck with the statue for at least two hundred years. 'Villano' had its own narrative etiology, which appears in the Tuscan prose romance The Book of Fioravante..$^{98}$ In this story one of the heroes, Fiovo, goes to Rome with I5,000 knights to help his uncle, the emperor 'Gostantino', who is besieged there by Saracens led by King Dinasor. Dinasor lands such a blow to Gostantino that he knocks even the saddle off the emperor's destrier; then all the other knights are unhorsed too, and the Christians flee on foot to the city. Some of them encounter a villano 'watching his oxen and his cows', who asks what has become of Gostantino, and after hearing the story, demands to be taken to see Dinasor. Threatening them with his 'enormous stick' (bastone), the peasant forces the refugees to lead him back to the battlefield, where they find Gostantino's horse without its saddle. 'And the peasant went up to him and caught him and mounted him without a saddle with the great stick on his shoulder and his ragged clothes tied in front of his chest and a pair of laced shoes on his feet'. ${ }^{99}$ Challenging Dinasor to joust, lance against bastone, the peasant unseats the Saracen king by 'extend[ing] his right arm, and lift[ing] him willy-nilly from his saddle', and carries him to Rome; then he returns to the battlefield to restore to the emperor his mount. The emperor (having to use a saddle) then wins the battle, but when the peasant returns to his animals he finds them all gone. Disgruntled, he goes back to the emperor with a demand: 'either you give me back my prisoner or you give me back my cows and my oxen, because I lost them on account of you.' The emperor promises him something far better: ${ }^{\text {Ioo }}$

...He summoned the best goldsmiths in all of Christendom and had them make a metal horse, and had them make on it the peasant with the stick in his hand and with the laced shoes 
on his feet, and he had everything made of metal, and he had the horse made without a saddle. And whoever goes to Rome can see it, and will see it as long as the world endures.

The tale is a reworking of the Mirabilia's story of the armiger, which in addition to transforming the squire into something more like a local Everyman, manages to retain a role for Constantine. ${ }^{\text {IOI }}$ It may also reflect some recent alterations to the monument: the captive is not accounted for and may have disappeared, and a stick may have been a transient addition. ${ }^{\text {IO2 }}$

While many readers were getting their history from romances, Petrarch was scouring monastic libraries for manuscripts of authentic Roman texts, and systematically collecting emperors' coins and medals. In the fifteenth century the new kind of scholarship represented by such efforts began to show spectacular results. Discussion of the statue of Marcus Aurelius was changed forever by the demonstration that the head was one of the imperial portraits seen on the ancient coins. The first to call it Marcus Aurelius may have been the author of a life of Pope Sixtus IV (I47I-84) credited by some to Platina (d. I48I). ${ }^{\text {I03 }}$ Since many bearded emperors look alike, however, the Marcusidentification did not immediately prevail over rival options favored by other humanist historians and numismatists: Commodus, Lucius Verus, Antoninus Pius, and Septimius Severus. ${ }^{104}$ Their disagreement was recorded in the learned guidebook of Bernardo Gamucci, published in $1565:{ }^{\text {:05 }}$

... in the center [of the Capitoline piazza] [is] that famous equestrian statue of Marcus Aurelius, brought there from the church of San Giovanni in Laterano in the time of Pope Paul m, which is called by the vulgar of our day il gran Villano. Some think that this statue is of Septimius Severus, and others think it is of Lucius Verus, which does not seem right to me, since it does not resemble in any way the true portrait of their medals.

Marcus Aurelius was the identification preferred by Pope Paul III, who finally accomplished the transfer of the statue from the peripheral Lateran campus to the area Capitolina in I538, and Marcus Aurelius was the name spelled out in the carefully worded inscriptions on the statue's new pedestal. ${ }^{106}$ Gamucci's guidebook indicates that even this decisive gesture did not impose consensus, however. The pope's own majordomo failed to cooperate, referring to the statue in his diary as 'the bronze horse of Constantine' ${ }^{107}$ As in the time of Master Gregory, there were again three interpretive positions around the statue, although they were differently disposed. The vox populi, still oral and still popular, now sustained the fiction of the 'Peasant'; humanists, hyperliterate and confident in the superiority of their new method of matching ancient texts with artifacts, insisted that the horseman must be Marcus Aurelius or a near contemporary; literates and subliterates outside this conversation continued to use the statue's first known name, Constantine, despite more than four centuries' efforts to suppress it. ${ }^{108}$

\section{Epilogue: Homo psychologicus}

The rediscovery of the original identity of the horseman was made possible by a much larger work of recovery, which included the texts mentioned at the beginning of this paper. With a name, therefore, the statue also acquired a biography. Because biographies varied considerably from one name to another, the continued learned quibbling over profiles and beard lengths was otiose. Once the statue was installed on the Capitol names like Commodus and Lucius Verus were not really possible; the rider could only be Marcus Aurelius, the best of rulers and the one fitting model for an enlightened Renaissance prince like Pope Paul III. ${ }^{109}$ The rightness of the name Marcus Aurelius was confirmed by Statius' Silvae, which was among the humanists' textual recoveries and brought with it the equestrian statue of Domitian. From Statius Renaissance interpreters learned the meaning of the rider's gesture: dextra vetat pugnas, the right hand forbids more battles. ${ }^{10}$ The first printed edition of the Silvae was issued in Venice in 1472, and Angelo Poliziano began to lecture on the poems in I480-8I. In I 489 he wrote that the statue of Marcus Aurelius was 'in the guise of a peacemaker' (pacificatore habitu). ${ }^{\text {III }}$ Michael Mezzatesta demonstrated the importance of this interpretation of the rider's gesture to the sixteenth-century idealization of the emperor as the model for all just and beneficent rulers, and he showed as well that the gesture became an independent signifier of moral character, appropriable for numerous portraits of high Renaissance princes, foremost the pope. ${ }^{\text {II2 }}$

Codes change; they transmute, devolve, are forgotten, and sometimes are recovered. The display of the imperial right hand, so rich in significance for the statue's original audience and for Renaissance readers of Statius, was a cipher to medieval interpreters, who had to invent stories to explain it. ${ }^{113}$ The curly hair that distinguished the Antonines and Septimius Severus from other emperors was part of a physiognomic code accessible to ancient Romans and to Renaissance numismatists but not to medievals, to whom it was part of the 'message without a code'. All audiences, however, ancient, medieval, Renaissance and later, knew the code of the horse. Two anonymous drawings made sometime after $153^{8}$ show the statue in its new location on the Capitol, approached by real riders who provide a point of comparison (figures $3 \mathrm{O}^{-}-3 \mathrm{I}$ ); this is especially clear in the drawing in Braunschweig (figure $3 \mathrm{I}$ ), in which the real horse is at the center and appears to strike the same pose as the bronze one. ${ }^{114}$ Intentionally or not, its juxtaposition to living horses is indicative of a prominent strain in the statue's critical fortune, the tendency to judge its quality by the degree of verisimilitude of the horse.

When it came to horses everyone was a critic. Gibbon noted that 'Horse connoisseurs admire the animal: others criticise it'. ${ }^{115}$ Winckelmann extolled the head: ${ }^{116}$ 


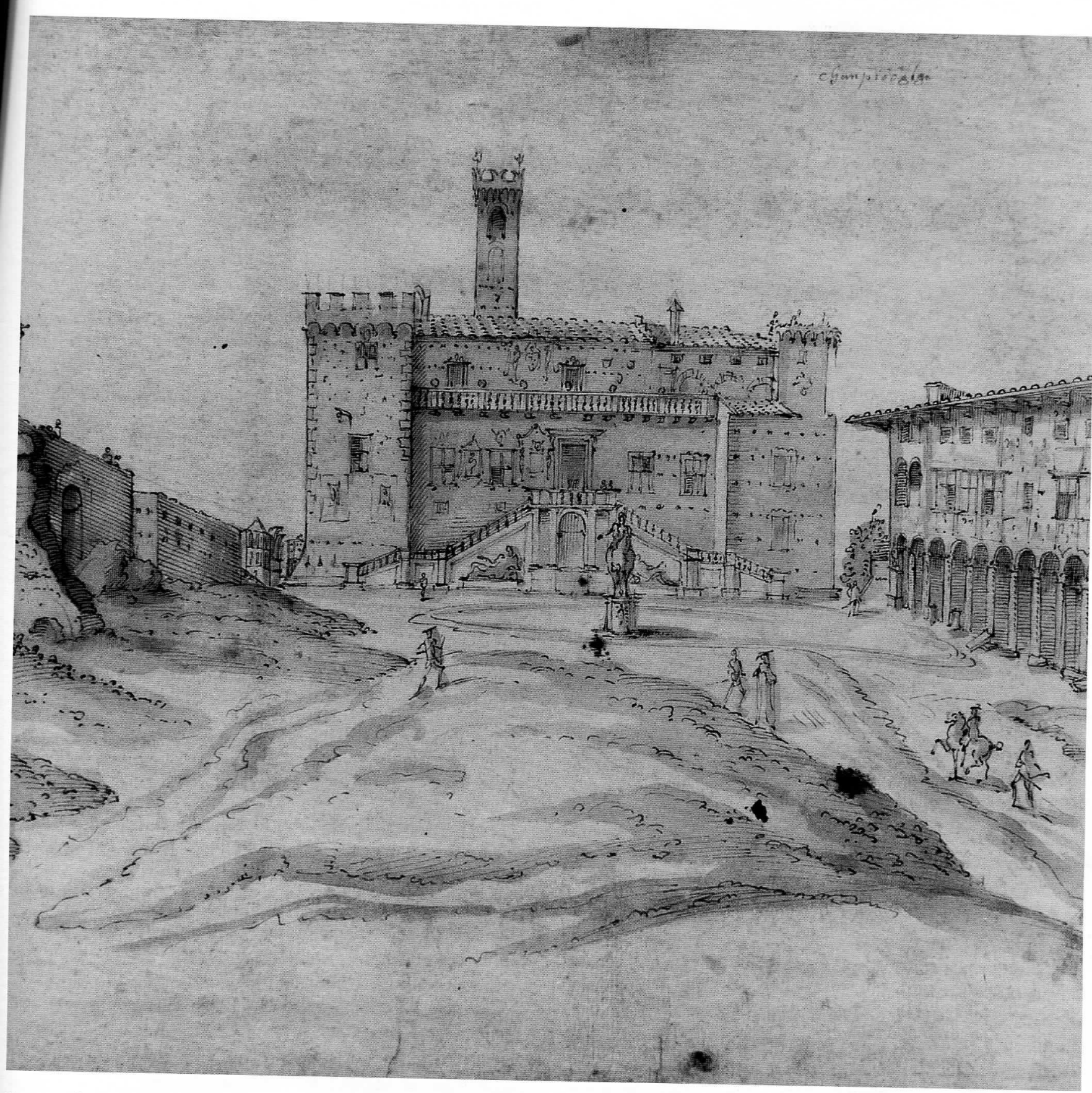
Figure 30. Paris, Musée du Louvre, Département des Arts Graphiques, Inv. I1028, anonymous drawing of the Area Capitolina after I538. Photo: Agence
Photographique, RMN.

There is in nature no head of a horse more beautiful and more spirited than that of the horse of Marcus Aurelius.

Étienne Falconet, however, decried the horse's shape, gait, proportions and general ugliness, and deplored its use as a model for sculptors. ${ }^{117}$ The poles of opinion were recorded and briefly analyzed by the nineteenth-century English traveler Joseph Forsyth, in the manner of Master Gregory and Bernardo Gamucci before him: ${ }^{118}$
The great statue of Marcus Aurelius, or rather of his horse, which was once the idol of Rome, is now a subject of contention. Some critics find the proportion of the animal false, and his attitude impossible. One compares his head to an owl's, another, his belly to a cow's; but the well-known apostrophé of the third will prevail in your first impression; the spirit and fire of the general figure will seduce the most practised eye... But it were unfair to judge of [the] excellence [of ancient sculptors] by this bruised and unfortunate animal 


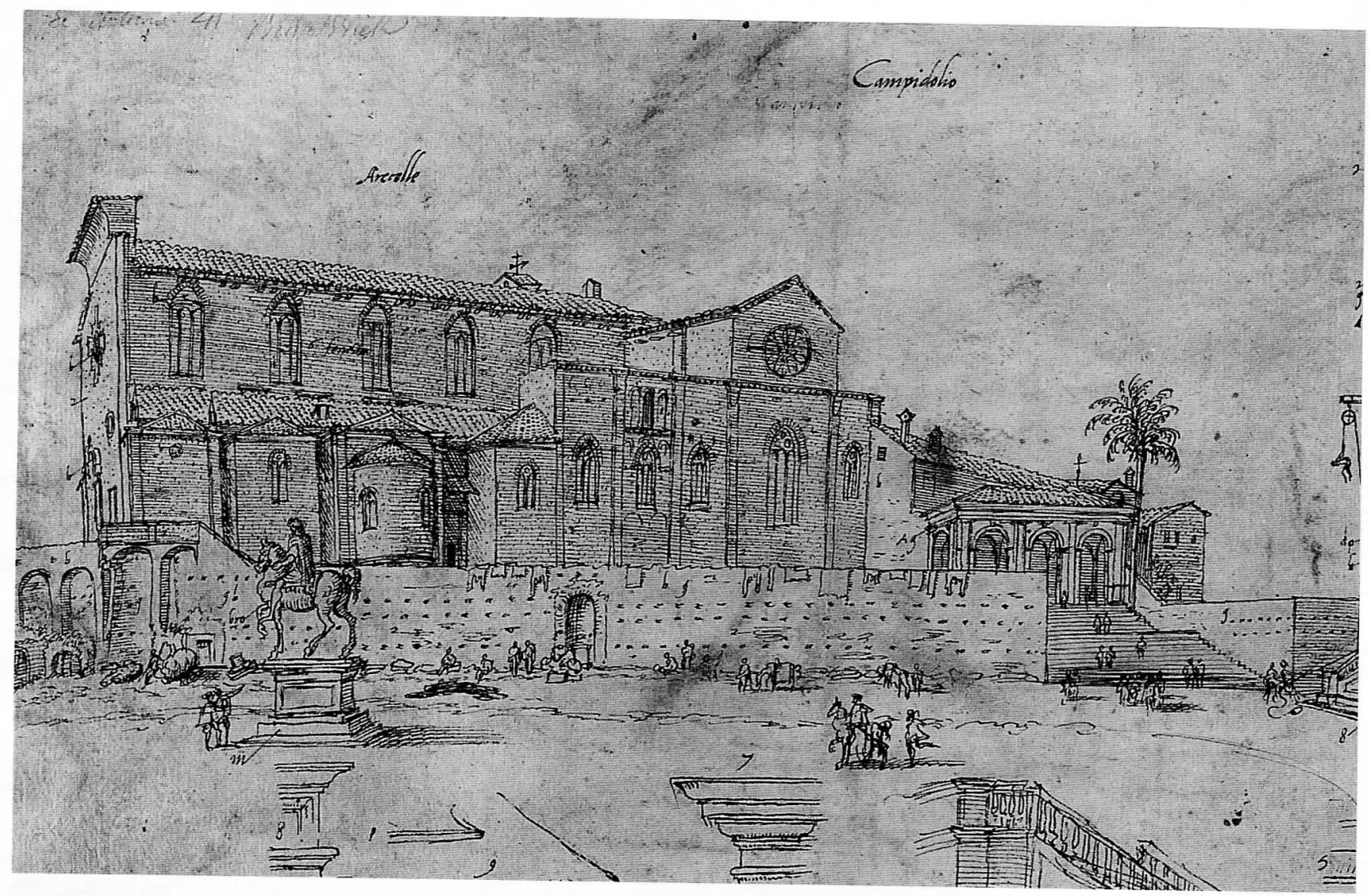

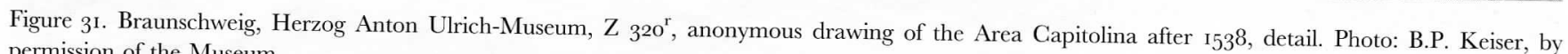
permission of the Museum.

\begin{abstract}
.. as the ancient bronze was too thin for figures of so large a volume. On some ancient rilievos, where the horse was traced con amore, we find all the truth, and spirit, and character which moderns have given to this noble animal, the subject of their severest study.
\end{abstract}

These debates are now moot, as horses are no longer seen on the Capitol and their place in the collective imagination of the viewing public has been occupied by cars. For modern interpreters the horse is just a 'message without a code', as the coiffure was for medievals. This semiotic displacement had a terrifying real-life corollary: it was also the automobile, as the chief source of reactive chemical pollutants in the atmosphere of modern Rome, that forced the bronze statue off its pedestal and into the glazed refuge in the Museo Capitolino.

It is interesting that the invention of the automobile is roughly contemporary with the invention of another transformative element of modern life, psychology. The coincidence was observed by Jacques Lacan: ${ }^{19}$

... a new type of man: Homo psychologicus [is] the product of our industrial age. The relations between this Homo psychologicus and the machines he uses are very striking, and this is especially so in the case of the motor-car....
Homo psychologicus ignores the horse and is drawn instead to the statue's face, the locus of expression thought to reveal interior dispositions. The result is yet another constellation of interpretive positions, including at least two within the hyperliterate community of archaeologists and art historians. One the one hand, sober taxonomists seek to classify the features among the possibilities offered by the emperor's successive portrait types, currently defining them as a pastiche of two types or an inexpert modification of one. ${ }^{120} \mathrm{On}$ the other hand, lyrical ekphrasts find that the face is encoded with traits of Marcus Aurelius' personality: ${ }^{\text {I2I }}$

The almost geometric scansion of the planes of the face characteristically helps to create the expression of calm, imperturbability, and detachment of the portraits of Marcus Aurelius, which is more pronounced here than in other examples...

$\ldots$ in its facial expression [the statue] is almost motionless, and radiates imperturbability and a certain distantness....

The portrait lacks any expression of vigor or will to power.

The language of lack is revealing. Medieval interpreters, at a loss to decode intended signifers, resorted to explaining gaps and absences: weapons, armor, a saddle, or in the case of the 
Quirinal Horse Tamers, the reins. Similarly the emptiness of the portrait's face is unbelievable to homo psychologicus, who is compelled to fill it.

To return to the terms of Roland Barthes, the equestrian statue, an intentional and 'frank' image like the photographic advertisement, has three messages: a linguistic message (the name of the emperor), a denoted iconic message, and a connoted message. The Renaissance discovery of the linguistic message moved all subsequent interpreters much closer to a correct (i.e. intended) understanding of the statue's denoted signifieds: we can now say that this is the emperor Marcus Aurelius, who ruled the Roman empire from I6I to I8o and in that time successfully fought off multiple incursions by non-Roman peoples along the eastern frontier. Success on this level does not automatically give access to connoted signifieds, however, much less to their associated 'euphoric values'. ${ }^{122}$ Connotations are in the realm of culture, and the culture of the militarized second-century imperial autocracy is discontinuous with that of the post-industrial plutocratic nation-state. As denizens of the latter we can only speculate about messages connoted in the former context. Perhaps the statue worked on second-century Romans, who might have seen it as the image of a military victor astride a magnificent equine machine, crushing a representative of an inferior but dangerous foreign population, to produce euphoric responses something like those intended by Trumph of the Will. To the heirs of Renaissance scholars, who see instead a mild and clement philosopher-king, effortlessly controlling a handsome mount whose foreleg curls innocuously in empty space, the euphoric values associated with the statue could hardly be more different; they are our values, and it is a happy dysfunction of the monument to promote them.

\section{NOTES}

*Phyllis Bober died on May 30, 2002, while this article was in press. I - Giulio Carlo Argan, in Marco Auretio. Storia di un monumento e del Suo Restauro, eds Alessandra Melucco Vaccaro and Anna Maria Sommella (Milan: Amilcare Pizzi, I989), p. I4.

2 - Giorgio Accardo, 'Von der Restaurierung zur Kopie. Ein Model für die Zukunft', in Marc Aurel. Der Reiter auf dem Kapitol (Munich: Hirmer Verlag, I999), pp. I4 $\mathbf{I}^{-2}$.

3 - For references see Phyllis Pray Bober and Ruth Rubinstein, Renaissance Artists \& Antique Sculpture. A Handbook of Sources (London and New York: Harvey Miller Publishers and Oxford University Press, I986), pp. 206-8, No. I76. The present article is dedicated to Phyllis, colleague and scholar extraordinaire, whose ground-breaking research on the afterlife of antique statues opened the way for my own work and for countless other studies in the same vein.

4 - Chiara Frugoni, 'L'antichità: dai 'Mirabilia' alla propaganda politica', in Memoria dell'antico nell'arte italiana, ed. Salvatore Settis, I (Turin: Giulio Einaudi, I984), pp. 3-70; Ingo Herklotz, 'Der Campus Lateranensis im Mittelalter', Römisches Jahrbuch für Kunstgeschichte, 22 (1985), pp. I-43; idem, Gli eredi di Costantino. Il papato, il Laterano e la propaganda visiva nel xI secolo (Rome: Viella, 200o), pp. 4${ }^{\mathrm{I}-94}$; Norberto Gramaccini, 'Die Umwertung der Antike - Zur Rezeption des Marc Aurel in Mittelalter und Renaissance', in Natur und Antike in der Renaissance, Liebieghaus Museum Alter Plastik, 5 December 1985-2 March 1986, exh. cat. (Frankfurt am Main: Liebieghaus, 1985), pp. $5^{\mathrm{I}-83}$; idem, Mirabilia. Das Nachleben antiker
Statuen vor der Renaissance (Mainz: P. von Zabern, 1996), pp. 145-58. See also Antonio Giuliano, 'La statua equestre di Marco Aurelio prima del suo trasferimento in Campidoglio', Xenia, 7 (I984), pp. 67-76; Lucilla De Lachenal, 'Il monumento nel Medioevo fino al suo trasferimento in Campidoglio', in Marco Aurelio, pp. 129-55; eadem, 'Il Gruppo equestre di Marco Aurelio e il Laterano. Ricerche per una storia della fortuna del monumento dall'età medievale sino al I538. Parte I', Bollettino d'arte, s. 6, 75/6 г (i990) pp. I-52; 'Parte I', ibid., 75/62-63 (1990), pp. I-56; Alessandra Melucco Vaccaro, 'Il monumento equestre di Marco Aurelio: restauro e riuso', in Marco Aurelio, pp. 211-52.

5 - The lecture series was sponsored by Hood College with support from the National Endowment for the Humanities. After several further presentations in the USA, the lecture was given in a condensed form at the xxixth International Congress of the History of Art at Amsterdam in 1996, but was withdrawn from the publication of that congress when the publication was too long delayed. The final oral redaction was given as the ICMA Lecture at the Courtauld Institute of Art in 200I. I would like to thank Anne Derbes for inviting me to give the original lecture at Hood College, Valentino Pace for including me in the meeting at Amsterdam, John Lowden for his hospitality in London, and Franz Alto Bauer and Jennifer Hirsh for their kind assistance in obtaining photographs for the present publication.

6 - Roland Barthes, 'Rhetoric of the Image', in Image Music Text, trans. Stephen Heath (New York: Hill \& Wang, 1977), pp. 36-7. Barthes claimed that only photographs can be uncoded, but this seems questionable, especially with respect to representations produced before photography was known. Photography is just the code that seems transparent to us, or seemed transparent before the widespread use of digital modification. 7 - Ibid., pp. 38-9. 8 - Dio's Roman History, Lxxi-Lxxi (Epitome of Xiphilinos), trans. Earnest Cary, ix [Loeb Classical Library] (New York: G. P. Putnam's Sons, 1927), pp. 2 -6I; Aurelius Victor, Liber de Caesaribus, I6, ed. and trans. Pierre Dufraigne, Aurelius Victor. Livre des Césars (Paris: Belles Lettres, 1975), pp. 20-3; Eutropius, Breviarium ab urbe condita, vin.1I-14, ed. Carlo Santini [Bibliotheca Teubneriana] (Leipzig: Teubner, I979), pp. 53-4; Julius Capitolinus, 'Marcus Antoninus the Philosopher', Scriptores Historiae Augustae, trans. David Magie, I [Loeb Classical Library, I92I] (repr. Cambridge, MA: Harvard University Press, 1979), pp. 132-205 (on the very complicated question of the date of this text see Histoire auguste, I. Introduction générale. Vies d'Hadrien, Aelius, Antonin, ed. and trans. J.-P. Callu [Paris: Belles Lettres, 1992], pp. XVI, XLV-XLVI). The first thirteen books of the history of Ammianus Marcellinus, which would have included the reign of Marcus Aurelius, were lost before the ninth century, but it is clear from passing references in the extant portions that Ammianus was favorably inclined: Ammianus Marcellinus, trans. John C. Rolfe, I [Loeb Classical Library, 1935] (repr. Cambridge, MA: Harvard University Press, I97I), pp. xvi, xliv-xlv.

9 - Dio's Roman History, Lxxir (Epitome of Xiphilinos), trans. Cary, Ix, pp. 68-9.

Io - Ammianus Marcellinus, Res gestae, xvi.I.4, trans. Rolfe, I, pp. 202-3; Julian, The Caesars, trans. Wilmer Cave Wright, Julian, II [Loeb Classical Library, I9I3] (repr. Cambridge, MA: Harvard University Press, 1969), pp. 344-4I5; Christian Lacombrade, 'L'Empereur Julien émule de Marc-Aurèle', Pallas. Annales de la Faculté des Lettres de Toulouse, I4 (1967), pp. 9-22. David Hunt argues against the standard view (and against the literary evidence) concerning Julian's emulation of Marcus Aurelius: 'Julian and Marcus Aurelius', in Ethics and Rhetoric. Classical Essays for Donald Russell on his Seventy-Fifth Birthday, eds Doreen Innes, Harry Hine, and Christopher Pelling (Oxford: Clarendon Press, 1995), pp. 287-98.

I - Cary, in Dio's Roman History, I, pp. xvii-xviii, xxii-xxiii; Giovanna Martinelli, L'ultimo secolo di studi sul Cassio Dione (Genoa: Accademia ligure di scienze e lettere, I999), pp. 2I-2, 39-40. Dio's Books XxxvI-Lxxx were epitomized by the Byzantine monk John Xiphilinos in the eleventh century, and the books treating Marcus Aurelius have come down in only that form. 
On the transmission of 'To Himself': Pierre Hadot, Marc Aurèle. Écrits pour lui-même, I (Paris: Belles Lettres, I998), pp. xIx-xxv; cf. The Communings with Himself of Marcus Aurelius Antoninus, Emperor of Rome, ed. and trans.

C. R. Haines [Loeb Classical Library, 1916] (repr. Cambridge, MA:

Harvard University Press, 1987).

I2 - See above, n. 8 fin.

I3 - Magie, in Scriptores Historiae Augustae, I, pp. xxiv-xxxii; Callu, in Histoire auguste, I, pp. Lxxiv-Lxxxir.

I4 - Orosius, Historiae adversus paganos, VII.I5, vII.27; ed. and trans. MariePierre Arnaud-Lindet, Orose. Histoires (Contre les Païens), in (Paris: Belles Lettres, I991), pp. 47-5o, 70-4.

15 - The Correspondence of Marcus Cornelius Fronto with Marcus Aurelius Antominus, Lucius Verus, Antoninus Pius, and Various Friends, ed. and trans. C. R. Haines, II [Loeb Classical Library, rev. 1930] (repr. Cambridge, MA: Harvard

University Press, 1987) pp. 300-5.

I6 - Dio's Roman History, Lxxin (Epitome of Xiphilinos), trans. Cary, Ix, pp. 28-9. H. Z. Rubin, 'Weather Miracles under Marcus Aurelius', Athenaeum, n.s. 57 (1979), pp. 357-80; Giovanna Martinelli, 'Il silenzio sui cristiani nella Storia Romana di Cassio Dione: un'ipotesi', Atti della Accademia Ligure di Scienze e Lettere, 47 (1990), pp. 437-4I.

I7 - Tertullian, Apologeticus, v.6; trans. T. R. Glover [Loeb Classical Library, 1931] (repr. Cambridge, MA: Harvard University Press, 1977), pp. $3^{-1}$.

I8 - Eusebius, Ecclesiastical History, Iv.xiv.Io-v.v.7; trans. Kirsopp Lake, I [Loeb Classical Library, I926] (repr. Cambridge, MA: Harvard University Press, I980), pp. $33^{8}-449$. At Iv.xiv.ro Eusebius recognizes that 'Antoninus Verus' was also Marcus Aurelius. For Marcus' several names see below, n. 22.

19 - Ibid., v.xxi.r.

20 - The martyrdoms at Smyrna may have occurred before Marcus; see Herbert Musurillo, The Acts of the Christian Martyrs. Introduction, Text and Translations (Oxford: Clarendon Press, 1972), p. xiii; Anthony Birley, Marcus Aurelius. A Biography (revised edn New Haven and London: Yale University Press, 1987), p. 261. Martyrdoms in Pergamon and Lyon and the death of Justin at Rome seem well fixed to his reign (Musurillo, pp. xv, $\mathrm{xviii}, \mathrm{xx}-\mathrm{xxi}$; Birley, p. 265).

21 - P. A. Brunt, 'Marcus Aurelius and the Christians', in Studies in Latin Literature and Roman History, ed. Carl Deroux, I [Collection Latomus, I64] (Brussels: Latomus, 1979), pp. 483-520, quotation on p. 498. Birley, Marcus Aurelius, pp. $264^{-5}$ has a different view.

22 - Marcus' birth name was Marcus Annius Verus; he became Marcus Aelius Aurelius Verus upon his adoption by Antoninus Pius in 138; as emperor he was known as Marcus Aurelius Antoninus; Birley, Marcus Aurelius, pp. 33, 49, I16-17. Orosius and Eutropius both refer to him as 'Marcus Antoninus'.

23 - Milan, Giviche Raccolte Archeologiche e Numismatiche, Gabinetto Numismatico; Francesco Gnecchi, I Medaglioni romani, II. Bronzo, pt. I, Gran modulo (Milan: V. Hoepli, I912), p. 29, No. 20, pl. 60.8 (ann. I77). 24 - Mirabilia urbis Romae, 6, eds Roberto Valentini and Giuseppe Zucchetti, Codice topografico della città di Roma, III (Rome: Istituto Storico Italiano per il Medio Evo, I946), p. 22: 'palatium Antonini, ubi est columpna'.

25 - Cf. Mary Beard, 'The Spectator and the Column: reading and writing the language of gesture', in La Colonne Aurélienne. Autour de la colonne Aurélienne. Geste et image sur la colonne de Marc Aurèle à Rome, eds John Scheid and Valérie Huet [Bibliothèque de l’École des Hautes Études Sciences Religieuses, I08] (Turnhout: Brepols, 2000), pp. 268-9.

26 - Philippe Lauer, Le Palais de Latran (Paris: E. Leroux, I9II), p. 310 , fig. II5, after Ciampini, De sacris aedificiis a Constantino Magno constructis (I693), pl. III. The statue is number 65 on the plan.

27 - Berlin, Staatliche Museen Preussischer Kulturbesitz,

Kupferstichkabinett, 79 D 2, fol. $71^{1}$; Christian Hülsen and Hermann Egger, Die römischen Skizzenbücher von Marten van Heemskerck im Königlichen Kupferstichkabinett zu Berlin, I (1913-16) (reprinted Soest: Davaco, 1975), pp. 36-9. Van Heemskerck was in Rome from 1532 to 1535 ; Elena Filippi, Maarten van Heemskerck. Inventio urbis (Milan: Berenice, 1990), p. I8. 28 - The villa was in the zone, but its location is not known precisely: P. Liverani, in Lexicon topographicum urbis Romae, ed. Eva Margareta Steinby, II (Rome: Quasar, 1995), p. I27 s.v. 'Domus: Laterani'. The barracks under the cathedral postdated Marcus Aurelius; they were the castra nova, constructed by Septimius Severus. The second-century castra priora were separated from the medieval site of the statue by the Arcus Caelimontani; see L. Richardson, Jr, A New Topographical Dictionary of Ancient Rome (Baltimore and London: Johns Hopkins University Press, I992), p. 62, fig. I6, p. 77 .

29 - Favoring an original location at the Lateran: Fittschen, in Klaus Fittschen and Paul Zanker, Katalog der römischen Porträts in den Capitolinischen Museen und den anderen Kommunalen Sammlungen der Stadt Rom, I, Text. Kaiser-und Prinzenbildnisse (Mainz: Philipp von Zabern, 1985), p. 73; Elfriede R. Knauer, 'Multa egit cum regibus et pacem confirmavit. The Date of the Equestrian Statue of Marcus Aurelius', Römische Mitteilungen, 97 (1990), pp. 279-8o. Valnea Santa Maria Scrinari's claim to have discovered the family villa and, in it, the original base of the statue under the present-day Ospedale di San Giovanni has been almost universally rejected; see Paolo Liverani, 'Note di topografia lateranense: le strutture di via Amba Aradam. A proposito di una recente pubblicazione', Bullettino della Commissione Archeologica Comunale di Roma, 95 (1993), Pp. I49, I51-2, nn. 64-5. Liverani prefers the argument of Claudio Parisi Presicce, that the statue was made for a monument in the Campus Martius near the Antonine Column: Parisi Presicce, 'Le assimetrie della statua equestre di Marco Aurelio. Un'ipotesi sul contesto originario', in Marco Aurelio, pp. 103-22; Liverani, 'Monumenti di epoca classica nel Patriarchio e nel Campo lateranense', in Il Palazzo Apostolico Lateranense, ed. Carlo Pietrangeli (Florence: Nardini, I99i), p. Io7. Mario Torelli thinks it more likely that the statue was first erected in the Forum: 'Statua Equestris Inaurata Caesaris: mos et ius nella statua di Marco Aurelio', in Marco Aurelio, pp. 83-I02; followed by Alessandra Melucco Vaccaro, 'Il monumento equestre', ibid., p. 2II.

30 - Herklotz, 'Der Campus Lateranensis', esp. pp. 34-42; followed by Gramaccini, 'Die Umwertung der Antike', pp. 54-5; idem, Mirabilia, p. I47; De Lachenal, 'Il Gruppo equestre - Parte I', pp. 2-4. For Herklotz's later reflections on his own thesis and its success see idem, Gli eredi di Costantino, pp. 2I2-I7.

$3^{\text {I }}$ - Gramaccini, 'Die Umwertung der Antike', pp. 56-7; idem, Mirabilia, pp. $14^{8-9}$.

32 - Le Liber pontificalis, ed. L'Abbé L. Duchesne, II (reprinted Paris: Éditions E. De Boccard, 198I), pp. 252, 259. References to the statue through the fifteenth century are conveniently collected by Giuliano, 'La statua equestre'.

33 - In Italy, the 'Regisole' in Pavia stood on a tall brick column in front of the cathedral, probably since the eleventh century; it may have been a statue of Theoderic taken from Ravenna (Cesare Saletti, Il Regisole di Pavia [Como: Edizioni New Press, 1997], pp. 15-31, 73-81); and according to Giovanni Villani, a stone equestrian statue was displayed on a pillar in Florence by $c .800$ (Michael Jacoff, The Horses of San Marco \& the Quadriga of the Lord [Princeton: Princeton University Press, 1993], pp. 65-8, 84-5). A second(?) statue of Theoderic in Ravenna was raised on a 'pyramid' of brick and stone six cubits high (Il Libro di Agnello storico. Le vicende di Ravenna antica fra storia e realtà, trans. Mario Pierpaoli [Ravenna: Diamond Byte, 1988], p. III [Ch. 94]); in 8or it was taken to Aachen, where it rose summis columnis (Hartmut Hoffmann, 'Die Aachener Theoderichstatue', in Das Erste Fahrtausend. Kultur und Kunst im werdenden Abendland an Rhein und Ruhr, I, ed. Victor H. Elbern [Düsseldorf: Verlag L. Schwann, I962], pp. 323, 326; Arne Effenberger, 'Die Wiederverwendung römischer, spätantiker und byzantinischer Kunstwerke in der Karolingerzeit', in 799. Kunst und Kultur der Karolingerzeit. Karl der Grosse und Papst Leo III. in Paderborm. Beiträge zum Katalog der Ausstellung Paderborn 1999, eds Christoph Stiegemann and Matthias Wemhoff [Mainz: Philipp von Zabern, 1999], pp. 653-6). Any or all of these examples may have been inspired by the equestrian statue of Justinian 
(originally Arcadius) that was displayed on a column outside the Augusteion in Constantinople since 543 (Franz Alto Bauer, Stadt, Platz und Denkmal in der Spätantike. Untersuchungen zur Ausstattung des öffentlichen Raums in den spätantiken Städten Rom, Konstantinopel und Ephesos [Mainz: Philipp von Zabern, I996], pp. I58-62). The thirteenth-century 'Magdeburg Rider', which was raised on something like a compound pier, is considered by some a reflection of the statue of Marcus Aurelius, by others an emulation of the monument to Justinian in Constantinople (Berent Schwineköper, 'Zur Deutung der Magdeburger Reitersäule', in Festschrift Percy Emst Schramm zu seinem siebzigsten Geburtstag, ed. P. Classen [Wiesbaden: Franz Steiner, 1964], pp. I32 9; Ernst Badstübner, 'Justinianssäule und Magdeburger Reiter', in Skulptur des Mittelalters Funktion und Gestalt, eds Friedrich Möbius and Ernst Schubert [Weimar: H. Böhlau, I987], pp. I84-210; Virginia Roehrig Kaufmann, 'The Magdeburg Rider: An Aspect of the Reception of Frederick II's Roman Revival North of the Alps', in Intellectual Life at the Court of Frederick In Hohenstaufen, ed. William Tronzo [Studies in the History of Art, 44] [Washington: National Gallery of Art, I994], pp. 63-88). 34 - Biblioteca Apostolica Vaticana, Vat. Lat. I96o, Paolino da Venezia, Chronologia magna, fol. $27 \mathrm{0}^{\mathrm{v}}$, after an original of $\mathrm{I} 32 \mathrm{I}$; Amato Pietro Frutaz, $L_{e}$ piante di Roma (Rome: Istituto di Studi Romani, I962), I, Testo, Pp. II5-20 and II, pl. Lxxiv. Princeton, University Library, Garrett MS. I58, Johannis Marcanovae Quaedam antiquitatum fragmenta (1465), p. xiv; Christopher S. Wood, 'Notation of visual information in the earliest archeological scholarship', Word E̊ Image, I7/I-2 (2001), p. 96; De Lachenal, 'Il Gruppo equestre - Parte II', pp. I6-I7. Florence, Biblioteca Laurenziana, Cod. Redi 77, foll. VII ${ }^{\mathrm{v}}$-VIII ${ }^{\mathrm{r}}$ (I474); Frutaz, Piante, I, pp. I39-4I, II, pl. LxxxIx. De Lachenal drew a conclusion opposite to mine, namely that medieval viewers' 'almost surreal' interpretation of some details must have been a result of the statue's great elevation on a column: 'Il monumento nel Medioevo', p. I30. The four stumps of columns in the foreground of van Heemskerck's drawing have been identified as the statue's medieval supports, which would have put it much closer to the ground; Philipp Fehl, 'The Placement of the Equestrian Statue of Marcus Aurelius in the Middle Ages', Journal of the Warburg and Courtauld Institutes, 37 (1974), pp. 362-7; Giuliano, 'La statua equestre', p. 7o; Jacoff, The Horses of San Marco, p. 85; Gramaccini, Mirabilia, p. I45.

35 - Giovanni Rucellai, 'Della bellezza e anticaglia di Roma', in Codice topografico, eds Valentini and Zucchetti, rv (Rome: Tipografia del Senato, I953), p. 408.

36 - Nikolaus Muffel, 'Beschreibung der Stadt Rom', in Codice topografico, rv, p. 354. Arnold Nesselrath, 'Simboli di Roma', in Da Pisanello alla Nascita dei Musei Capitolini. L'Antico a Roma alla vigilia del Rinascimento, Musei Capitolini, 24 May-I9 July I988, exh. cat. (Milan/Rome: Arnoldo Mondadori/De Luca Edizioni d'Arte, I988), p. 203; De Lachenal, 'Il Gruppo equestre Parte II', p. I5.

37 - Arnold Nesselrath, in Da Pisanello alla Nascita dei Musei Capitolini, cat. 8o, pp. 232-3; De Lachenal, 'Il Gruppo equestre - Parte I', pp. I-I7. $3^{8}$ - Rome, Santa Maria sopra Minerva, Carafa Chapel, The Trumph of St. Thomas Aquinas; Gail L. Geiger, Filippino Lippi's Carafa Chapel. Renaissance Art in Rome (Kirksville, MO: Sixteenth Century Journal Publishers, Ig86), Pp. I03-4. Arnold Nesselrath, Das Fossombroner Skizzenbuch (London: University of London, Warburg Institute, I993), pp. I77-8 lists all known drawings of the statue made between 1474 and 1538 , as well as some before and after; see also De Lachenal, 'Il Gruppo equestre - Parte I', pp. I8-30; Gramaccini, 'Die Umwertung der Antike', pp. 69-8o.

39 - Fittschen, in Fittschen and Zanker, Katalog, p. 73; Knauer, 'Multa egit cum regibus', pp. 289-90, 302-3; eadem, 'Bruchstück einer bronzenen Satteldecke in Bonn. Nachtrag', Bonner Jahrbücher, I95 (I995), pp. 439-46; Johannes Bergemann, Römische Reiterstatuen. Ehrendenkmäler im öffentlichen Bereich (Mainz: Philipp von Zabern, 1990), pp. Io6-7.

40 - Helmut Nickel, 'The Emperor's New Saddle Cloth: The Ephippium of the Equestrian Statue of Marcus Aurelius', Metropolitan Museum Fournal, 24 (1989), p. 2r; Elfriede R. Knauer, 'Bruchstück einer bronzenen Satteldecke in Bonn', Bonner Jahrbücher, 192 (I992), pp. 243-6o.
4I - Parthenay-le-Vieux, Saint-Pierre, left portal of west façade; René Crozet, L'art roman en Poitou (Paris: Henri Laurens, I948), p. 78, pl. xxx; Maurice Poignat, Parthenay et la Gatine (Poitiers: M. Fontaine, I993), pp. 75-6. Autun, Saint-Lazare, choir pier capital; Denis Grivot and George Zarnecki, Gislebertus Sculptor of Autun (New York: Orion Press, I96I), p. 65, pl. 6; Linda Seidel, Legends in Limestone. Lazarus, Gislebertus, and the Cathedral of Autun (Chicago and London: University of Chicago Press, 1999), pp. I57-8. There are also medieval relief images of 'Constantine' in Italy: Kaufmann, 'The Magdeburg Rider', p. 70.

42 - Fehl, 'The Placement of the Equestrian Statue', p. 366; J. Falus, 'Some Iconographic Questions of the Equestrian Statue of Marcus Aurelius', Acta Historiae Artium, 26 (I980), p. I71. Knauer, 'Multa egit cum regibus', pp. $284-5$ argues against the originality of the trampled captive on formal grounds.

43 - Dio's Roman History, Lxxin (epitome of Xiphilinos), trans. Cary, Ix, pp. 24-7; the emperor did offer a higher reward (Iooo gold pieces) for capturing Ariogaesus alive.

44 - Nickel, 'The Emperor's New Saddle Cloth', p. 22. Because of the 'Persian' saddle blanket Knauer has sought to identify the occasion commemorated by the statue as one involving the Parthians; Nickel's posited connection with the Iazygids is more straightforward.

45 - The earliest such drawing is the one in the Castello Sforzesco attributed by Nesselrath to Pisanello, c. I430: Nesselrath, in Da Pisanello alla Nascita dei Musei Capitolini, pp. 232-3.

46 - London, British Museum, CM i978.10-21.5. Luigi Canina, Foro Romano e sue adiacenze. Tavole (2nd edn, Rome: Canina, i845), pl. Ix. Bergemann, Römische Reiterstatuen, pp. I64-6; C. F. Giuliani, in Lexicon topographicum urbis Romae, II, p. 228, s.v. 'Equus: Domitiani'. 47 - The following quotations are from the translation of Silvae, r.i by J. H. Mozley, Statius, I [Loeb Classical Library, 1928] (reprinted Cambridge, MA: Harvard University Press, I982), pp. 7-15. See the analysis of these poems' structure by Stephen Thomas Newmyer, The Silvae of Statius. Structure and Theme (Leiden: E.J. Brill, I979), esp. ch. 4.

48 - Dale Kinney, 'Spolia. Damnatio and Renovatio Memoriae', Memoirs of the American Academy in Rome, 42 (1997), p. I37.

49 - F. Castagnoli, 'Note numismatiche', Archeologia classica, 5 (I953), p. 108. 50 - Though it is a commonplace that Statius was widely read by medievals, they were reading the Achilleid and the Thebaid. The Silvae were lost until the single manuscript was discovered by Poggio Bracciolini $c$. I4I6; Robert Dale Sweeney, Prolegomena to an Edition of the Scholia to Statius (Leiden: E. J. Brill, I969), p. I, n. I; M.D. Reeve, 'Statius' Silvae in the Fifteenth Century', Classical Quarterly, 27 (I977), Pp. 202-3, 220-I. 5I - Virgil, Georgics, III.75-88, trans. H. Rushton Fairclough, Virgil, I [Loeb Classical Library, revised edn 1935] (reprinted Cambridge, MA: Harvard University Press, I974), pp. I6o-1. See also Ann Hyland, Equus: the Horse in the Roman World (London: B.T. Batsford, I990), pp. 5-10. $5^{2}$ - Muybridge's Complete Human and Animal Locomotion. All 781 Plates from the I887 Animal Locomotion by Eadweard Muybridge, III (New York: Dover Publications, I979), esp. pp. II70-7I, pl. 577; p. I200, pl. 592. Cf. Albertus Magnus, De animalibus, xxII, tract 2, ch. I, 54: 'Horses display four kinds of gaits: the gallop or run...; the trot; the walk; and the canter.... The trot is more rapid than the walk, but the horse lifts one forefoot and the hindfoot on opposite sides at the same time.... In ordinary walking, the horse puts down a forefoot and the hindfoot on the same side of the body together'; trans. James J. Scanlan, Albert the Great. Man and the Beasts, de animalibus (Books 22-26) (Binghamton: State University of New York, Center for Medieval and Early Renaissance Studies, 1987), p. IO5. 53 - Ludwig Heydenreich, 'Marc Aurel und Regisole', in Festschrift für Erich Meyer zum sechzigsten Geburtstag 29. Oktober 1957 (Hamburg: E. Hauswedell, I959), p. I55, n. 23; Claudio Parisi Presicce, 'Il monumento equestre di Marco Aurelio. Scheda storico-archeologica', in Marco Aurelio, p. 20; Raimund Wünsche, 'Der Kaiser zu Pferd', in Marc Aurel, p. 6o; Reinhold Baumstark, 'Das Nachleben der Reiterstatue', ibid., p. 99. 'Teachable tool' (gelehriges Werkzeug) is from Baumstark. 
54 - A. Azzaroli, An Early History of Horsemanship (Leiden: E. J. Brill/ Dr W. Backhuys, 1985), p. 156 . Azzaroli calls Marcus' horse a new type in sculpture, 'large and robust but not heavy'; 'full of temperament but of more delicate constitution [than Greek horses]'.

55 - Accardo, 'Von der Restaurierung zur Kopie', p. I63.

56 - The idea that the French reliefs were somehow connected with the statue of Marcus Aurelius goes back to the seventeenth century, when it was proposed for the relief at Parthenay-le-Vieux (figure i5); see Crozet, L'art roman en Poitou, p. 209. It was popularized by Émile Mâle, Religious Art in France. The Tweelfth Century. A Study of the Origins of Medieval Iconography (1922; revised 1953), trans. Marthiel Mathews [Bollingen series go.I] (Princeton: Princeton University Press, 1978 ), pp. 248-51. Many scholars have opposed it, e.g. René Crozet, 'Nouvelles remarques sur les cavaliers sculptés ou peints dans les églises romaines', Cahiers de civilisation médiévale $X^{p}-X I f$ siècles, I (1958), pp. 27-36 (reversing the position of L'art roman en Poitou, pp. 209-Io). In Songs of Glory. The Romanesque Facades of Aquitaine (Chicago and London: University of Chicago Press, 198I), Linda Seidel gives an extended and subtle demonstration of the permeability of the image - whatever its ultimate origin - to a world of meanings topical, traditional, learned, and popular. By contrast, Chiara Frugoni posits a relatively limited range of political and literate interpretations: 'L'antichità', pp. 32-53.

57 - The Itinerary of Benjamin of Tudela. Travels in the Middle Ages, introductions by Michael A. Signer, Marcus Nathan Adler, A. Asher, trans. Marcus Nathan Adler (Malibu: Joseph Simon/Pangloss Press, 1987), p. 64

58 - Translated from Mirabilia urbis Romae, I5, in Codice topografico, III, pp. $3^{2-3}$. Internal evidence reveals that the Mirabilia urbis Romae was written shortly before 1143 .

59 - H. Jordan, Topographie der Stadt Rom im Alterthum, II (Berlin:

Weidmannsche Buchhandlung, $187 \mathrm{I}$ ), p. 386 (the author was 'moved by the spirit of his time, which hoped for the resurrection of the Roman republic'); similarly Ferdinand Gregorovius, History of the City of Rome in the Middle Ages (I8go), IV, II, trans. Annie Hamilton (London: George Bell \& Sons, I896), p. 664; Arturo Graf, Roma nella memoria e nelle immaginazioni del medio evo (Turin: Ermanno Loescher, I9I5), p. 47.

6o - Herklotz, 'Der Campus Lateranensis', pp. 26-7; idem, Gli eredi di Costantino, pp. 213-17; Gramaccini, 'Die Umwertung der Antike', pp. 51-8; idem, Mirabilia, pp. I50-2; De Lachenal, 'Il Gruppo equestre - Parte I', pp. I-4.

6I - Frugoni, 'L'antichità', esp. pp. 63-5, 7 7 -2

62 - Magister Gregorius (I2 $2^{e}$ ou $13^{e}$ siècle), Narracio de Mirabilibus urbis Rome, 4, ed. R. B. C. Huygens [Textus minores, 42] (Leiden: E. J. Brill, 1970). The treatise has been translated into Italian, with an excellent bibliography, by Cristina Nardella, Il fascino di Roma nel Medioevo. Le 'Meravighie di Roma' di maestro Gregorio [La corte dei papi, I] (Rome: Viella, 1997), and into English, with a thorough commentary, by John Osborne, Master Gregorius. The Marvels of Rome [Mediaeval Sources in Translation, 3i] (Toronto: Pontifical Institute of Mediaeval Studies, 1987). On the date see Osborne, pp. I4 $^{-15}$.

63 - Master Gregorius, trans. Osborne, pp. 19-20.

64 - They were described as interpretive communities by Walter Cahn, 'Romanesque Sculpture and the Spectator', in The Romanesque Frieze and its Spectator, ed. Deborah Kahn (London: Harvey Miller, 1992), p. 55.

65 - Gramaccini explains Theoderic as a product of German 'national pride'; Mirabilia, p. I50.

66 - Master Gregorius, trans. Osborne, pp. 20-I.

67 - Livy, Ab urbe condita, vir.vi.I-6, trans. B.O. Foster, Livy, III [Loeb Classical Library, 1924] (reprinted Cambridge, MA: Harvard University Press, 1940), pp. 372-5. Marcus Curtius was 'fully armed' [armatum] and mounted on a horse 'caparisoned with all possible splendour' [quam poterat maxime exomato $]$ when he heroically threw himself into a chasm.

68 - Albin Lesky, 'Ein verschollenes Aition zur Reiterstatue des Mark Aurel', Wiener Studien, 6I-62 (1943-44), p. I9I; cf. Cahn, 'Romanesque Sculpture', p. $5^{8}$.
69 - Elaborating on Gregorovius' position that the Mirabilia originated 'in the time of the Ottos', Gramaccini suggested that the story grew up around the tenth-century communal hero Alberic: Gramaccini, 'Die Umwertung der Antike', p. 58; idem, Mirabilia, pp. I5I-2; cf. Gregorovius, History of the City of Rome, IV, II, p. 655, n. I. This has the effect of displacing the matrix of the tale from one political episode to another, earlier one. I am suggesting instead an origin in popular culture not determined by factional politics, though not necessarily unaware of them.

70 - Commenting on a fad for temporarily decorating American cities with life-size statues of animals and people, one city official observed that 'People gather around these objects and start talking to strangers'; reported in the New York Times, dateline August I6, 200I (thanks to Mark Darby for this reference). For the ancient parallels I am indebted to the $\mathrm{PhD}$ dissertation by Terrance J. Rusnak, Jr, 'The Active Spectator: Art and the Viewer in Ancient Greece' (Bryn Mawr College, 200I).

7 I - Anthologia Graeca, ed. Hermann Beckby (2nd edn, Munich: Heimeran, I965), II, p. 252; trans. W. R. Paton, The Greek Anthology, II, VII.424 [Loeb Classical Library, 1917] (reprinted New York: G. P. Putnam's Sons, 1925), pp. 230-I; cited by Rusnak, 'The Active Spectator', p. III. The epigram came from the first-century-BCE Stephanos of Meleager of Gadara, where it was credited to Antipater of Sidon (170-10o): cf. Beckby, Anthologia Graeca, I, pp. 37-8, 69-70; Paton, Greek Anthology, I, p. vii. On the Greek Anthology see Elizabeth M. Jeffreys, in The Oxford Dictionary of Byzantium (New York and Oxford: Oxford University Press, 1991), II, pp. 872-3.

72 - Anthologia Graeca, viI.428, ed. Beckby, II, pp. 254-6; trans. Paton, II, pp. 232-5; the epigram is credited to Meleager. For similar examples see ibid., VII.42I, 422, 423,425, 426, 427,429 , all concerning grave stelai, and Xvi.275, an epigram by Posidippus on the emblematic statue of Time Fleeing by Lysippus. Cf. Rusnak, 'The Active Spectator', pp. Ioo-II. 73 - Wace, Le Roman de Rou, III, 3043-52; ed. A. J. Holden, I (Paris: Éditions A. and J. Picard, 1970), p. 274; Frugoni, 'L'antichità', p. 39. 74 - Varro, Rerum rusticarum libri, i.vii.I5, trans. William Davis Hooper, Marcus Porcius Cato On Agriculture and Marcus Terentius Varro On Agriculture, revised Harrison Boyd Ash [Loeb Classical Library, 1934] (reprinted Cambridge, MA: Harvard University Press, 1993), pp. 390-I.

75 - Albertus Magnus, De animalibus, xxII, tract 2, ch. I, 53, ed. Hermann Stadler, Albertus Magnus De Animalibus Libri xxvi nach der Cölner Urschrift, II [Beiträge zur Geschichte der Philosophie des Mittelalters, I6] (Münster i.W.: Aschendorff, 1920), p. I378: 'sunt autem aput nos inter domitos equos quatuor modi equorum, bellici videlicet qui dextrarii vocantur, et palefridi et curriles equi et runcini vocati'. Trans. Scanlan, Albert the Great, p. I04. 76 - R. H. C. Davis, 'The Medieval Warhorse', in Horses in European Economic History. A Preliminary Canter, ed. F. M. L. Thompson (Reading: British Agricultural History Society, 1983), p. 4; B. Ribémont, in Brigitte Prévot and Bernard Ribémont, Le Cheval en France au Moyen Age; sa place dans le monde médiéval; sa médecine: l'exemple d'un traité vétérinaire du XIV siècle, La Cirurgie des chevaux (Orléans: Paradigme, 1994), pp. 178-9.

77 - Davis, 'The Medieval Warhorse', pp. $4^{-1}$; Ribémont, in Le Cheval en France, pp. $173^{-255}$.

78 - Albertus Magnus, De animalibus, xxII, tract 2, ch. I, 52, ed. Stadler, p. I377; trans. Scanlan, p. 103.

79 - Carolus Dufresne Dominus Du Cange, Glossarium Mediae et Infimae Latinitatis, ed. G. A. L. Henschel, I (Paris: Firmin Didot, I840), p. 402; Charles Oman, A History of the Art of War. The Middle Ages from the Fourth to the Fourteenth Century (New York: G. P. Putnam's Sons, 1898), pp. 370-3. 80 - Bayeux Tapestry, 'The knights (milites) go forth from Hastings'; Wolfgang Grape, The Bayeux Tapestry. Monument to a Norman Triumph (Munich and New York: Prestel, 1994), pp. I44-5.

8r - Sandra Barberi, Il Chiostro di S. Orso ad Aosta (Rome: 'L'Erma' di Bretschneider, I988), pp. 26-7; Robert Berton, Aosta. I Capitelli del Chiostro di Sant'Orso (Aosta: Tipografia Valdostana, 199I), pp. 86-8; Amato Pietro Frutaz, 'Redazione inedita della "Vita Beati Ursi Presbyteri et Confessoris de Augusta Civitate", Mélange de documents historiques et hagiographiques valdôtains (Miscellanea Augustana), II, par l'école des chartes (Aosta: Itla, 1953), 
pp. $327-8$. In the text tradition of the episode, which goes back at least to the ninth century, the boy is called cavallarius rather than armiger as on the capital.

82 - Rome, Museo Nazionale delle Terme, No. 108437 (detail), c. 170-80; Bernard Andreae, Motivengeschichtliche Untersuchungen zu den römischen Schlachtsarkophagen (Berlin: Gebr. Mann, I956), p. I4 and passim; Luisa Musso, in Museo Nazionale Romano. Le Sculture, ed. Antonio Giuliano, I, 8, pt. I (Rome: De Luca Editore, I985), No. vi, 5, pp. 268-7o.

83 - Aelius Spartianus, 'Antoninus Caracalla', vir. I-2, in Scriptores Historiae Augustae, ed. David Magee, In [Loeb Classical Library, I924] (reprinted Cambridge, MA: Harvard University Press, I980), pp. 18-19. 84 - New York, The Pierpont Morgan Library, M. 638, fol. 33, I Samuel 24.I-7; Sydney C. Cockerell and John Plummer, Old Testament Miniatures. A Medieval Picture Book with 283 Paintings from the Creation to the Story of David (New York: George Braziller, c. 1969), p. 154, no. 203; p. I55. 85 - Genesis 27, 30-3I (Jacob); I Samuel I7 (David). 86 - Mirabilia urbis Romae, I2, in Codice topografico, III, Pp. 30-I. 87 - Hebrews 4.I3; Erwin Panofsky, Studies in Iconology (I962; reprinted New York, Hagerstown, etc.: Harper \& Row, I972) pp. I55-6, n. 93. 88 - Andreas Thielemann, 'Roma und die Rossebändiger im Mittelalter', Kölner Jahrbuch, 26 (1993), pp. 85-131, quoted phrase on p. $9^{8 .}$

89 - Ibid., pp. 96, 98-9.

90 - Thielemann similarly compares the story of the Horse Tamers to the Gesta Romanorum: 'Roma und die Rossebändiger', pp. Ioo-2. Brigitte Weiske argues that the Gesta Romanorum originated in a Franciscan milieu before I284, but this date applies to the collection of the tales and their moralizations rather than to the tales themselves, which came from diverse sources, including ancient ones; Gesta Romanorum, I, Untersuchungen zu Konzeption und Überlieferung (Tübingen: Max Niemeyer, I992), pp. 183-98. There were Latin and vernacular versions of the Gesta Romanorum. The oldest Latin manuscript $(\mathrm{J})$ is dated $\mathbf{I} 34^{2}$.

9I - J, cap. 42 and cap. I2, ed. Wilhem Dick, Die Gesta Romanorum. Nach der Innsbrucker Handschrift vom Fahre 1342 und vier Münchner Handschriften (Erlangen and Leipzig: A. Deichert'sche Verlagsbuchh., I89o), pp. 42, I2.

92 - On the character of the tales see Gesta Romanorum. Römergeschichte aus dem Mittelalter, trans. Franz Peter Waiblinger (Munich: Deutscher

Taschenbuch, 1992), pp. 6-9.

93 - J., cap. 5o, ed. Dick, Gesta Romanorum, pp. 33-4; Hermann Oesterley, Gesta Romanorum (Berlin: Weidmannsche Buchhandlung, I872), Pp. 321-2, cap. 25; trans. Charles Swan, Gesta Romanorum, revised Wynnard Hooper (London: G. Bell \& Sons, I912), p. 57. Oesterley's text is that of the editio princeps of the I470s; Swan's translation of the moral is abridged.

Remarkably, another chapter of the Gesta Romanorum retells the story of Marcus Curtius with a hero named 'Marcus Anilius', translated by Swan as 'Marcus Aurelius': J, cap. 97, ed. Dick, p. 57; Swan and Hooper, pp. $77^{-8 .}$

94 - Linda Seidel compared the narratives of the Mirabilia urbis Romae to exempla used by preachers: Legends in Limestone, pp. 85-6, г78, n. II. 95 - Gramaccini, on the contrary, finds Master Gregory's retelling a 'qualitative improvement'; Mirabilia, p. I53. The 'omission of the unpleasant' is one of several characteristic alterations observed by F. C. Bartlett in the oral transmission of 'primitive' folk tales by people with modern education: 'Some Experiments on the Reproduction of Folk Stories' (1920), reprinted in The Study of Folklore, ed. Alan Dundes (Englewood Cliffs, NJ: Prentice Hall, ig65), Pp. 250-I. Master Gregory is not the only one to follow this pattern in retelling the story of the armiger, E. Rodocanachi, The Roman Capitol in Ancient and Modern Times, trans. Frederick Lawton (London: William Heinemann, I9o6), p. I32, repeats everything except the reason for the king's nightly visits to the tree.

96 - Cited by Thielemann, 'Roma und die Rossebändiger', p. I29, n. 30I. 97 - Fazio degli Uberti, Dittamondo, Ir.xxxi, in Codice topografico, rv, p. 62. On the poem see Storia della letteratura italiana, ed. Enrico Malato, II (Rome: Salerno Editrice, I995), pp. 437-42.
98 - Pio Rajna, Ricerche intorno ai Reali di Francia, seguite dal Libro delle Storie di Fioravante e del Cantare di Bovo d'Antona [I Reali di Francia, I] (Bologna: Gaetano Romagnoli, I872), pp. 36I-4; Graf, Roma nella memoria ... del medio evo, pp. 459-6o. On The Book of Fioravante see Daniela Delcorno Branca, Il romanzo cavalleresco medievale (Florence: G. C. Sansoni, 1974), pp. 17-18; Storia della letteratura italiana, II, pp. 949-50.

99 - Rajna, Ricerche, p. $3^{62}$.

Ioo - Ibid., p. 364 .

Iог - Gramaccini, who ascribes political motives to all descriptions of the statue, describes Fioravante's version as a 'Ghibelline reinterpretation': 'Die Umwertung der Antike', p. 65. Herklotz is skeptical; Gli eredi di Costantino, p. 215 .

IO2 - The omission of the captive corroborates De Lachenal's suggestion that this figure was lost during the Avignon papacy: 'Il Gruppo equestre Parte II', p. 4.

103 - 'Vita Sixti Iv. auctore anonymo', in Ludovico Antonio Muratori, Rerum italicarum scriptores ab anno aerae christianae quingentesimo ad

millesimumquingentesimum..., III, 2 (Milan: Typographia Societatis Palatinae, I734), col. I064; published as Platina's work by Giacinto Gaida, Platynae

Historici Liber de vita Christi ac omnium pontificum, in Raccolta degli storici italiani dal cinquecento al millecinquecento ordinata da L. A. Muratori, eds Giosue Carducci and Vittorio Fiorini, III, I (Città del Castello: S. Lapi, n.d.), p. 4I8; cf. Codice topografico, rv, p. 45 o, n. 4 .

I04 - Tilmann Buddensieg, 'Zum Statuenprogramm im Kapitolsplan Pauls III.', Zeitschrift für Kunstgeschichte, 32 (1969), pp. 217-18, n. II; Christof Thoenes, "Sic Romae". Statuenstiftung und Marc Aurel', in Ars naturam adiuvans. Festschrift für Matthias Winner zum II. Marz 1996, eds Victoria v.

Flemming and Sebastian Schütze (Mainz: Philipp von Zabern, I996), p. 9I. I05 - Quoted by James S. Ackerman, 'Marcus Aurelius on the Capitoline Hill', Renaissance Newes, Io (1957), p. 70.

ro6 - 'M[arcus] Aurelius Antoninus Pius'; cf. n. 22 above. 'Pius' is a mistake; Giovanni Giacomo Pani, 'Considerazioni ed ipotesi in margine all'iscrizione IMP. CAESARI DIVI ANTONINI F. etc. sul basamento della statua equestre di Marco Aurelio in Campidoglio', Archivio della Società Romana di Storia Patria, I03 (1980), p. 316. 107 - '. . locum Capitolij nouiter explanatum cum aequo aeneo Constantini ex Laterano translato...'; quoted by Paul Künzle, 'Die Aufstellung des Reiters vom Lateran durch Michelangelo', Miscellanea Bibliothecae Hertzianae [Römische Forschungen der Bibliotheca Hertziana, I6] (Munich: Anton Scholl, I96r), p. 257, n. 8. Io8 - On 'Constantine's' survival see, in addition to the diary of the papal cerimoniere Biagio da Cesena quoted in $\mathrm{n}$. 107, the diary of one Cola Coleine of Trastevere: 'Adi xxin de marzo mDxxxvin lo di de San Pietro San Pauolo, lo cauallo de Costantino fu messo nella piazza de Campitoglio'; quoted by Künzle, 'Die Aufstellung des Reiters,' p. $25^{8}$. Io9 - On the meaning of Marcus Aurelius for Pope Paul III see Michael P. Mezzatesta, 'Marcus Aurelius, Fray Antonio de Guevara and the Ideal of the Perfect Prince in the Sixteenth Century', Art Bulletin, 66 (1984), pp. 620-9; Buddensieg, 'Zum Statuenprogramm', pp. I88-92; Thoenes, 'Sic Romae', pp. 9I-6. I 10 - Statius, Silvae, r.i.37. II - Reeve, 'Statius' Silvae in the Fifteenth Century', pp. 207, 217; Buddensieg, 'Zum Statuenprogramm', p. 220, n. 35 . I12 - Mezzatesta, 'Marcus Aurelius', pp. 621-4, 628-33. $I_{3}$ - Richard Brilliant, Gesture and Rank in Roman Art. The Use of Gestures to Denote Status in Roman Sculpture and Coinage [Memoirs of the Connecticut Academy of Arts \& Sciences, xrv] (New Haven: Connecticut Academy of Arts \& Sciences, 1963), p. 96.

II4 - Paris, Louvre, Département des Arts Graphiques, Inv. I1028; Hermann Egger, Römische Veduten. Handzeichnungen aus dem XV. bis XVII. Jahrhundert zur Topographie der Stadt Rom, II (Vienna: Anton Scholl \& Co., I93I), p. Io, pl. 4. Braunschweig, Herzog Anton Ulrich-Museum, Z $3^{20}$; Egger, ibid., p. Io, pl. 3. De Lachenal, 'Il Gruppo equestre - Parte II', pp. $44^{-6 .}$ 
II5 - Gibbon's Fourney from Geneva to Rome. His fournal from 20 April to 2 October ${ }_{1764}$, ed. Georges A. Bonnard (London, Edinburgh etc.: Thomas Nelson and Sons, $196 \mathrm{I}$ ), p. 239

II6 - Storia delle Arti del Disegno presso gli Antichi di Giovanni Winkelmann, trans. Carlo Fea, I (Rome: Stamperia Pagliarini, I783), pp. 388-9; Francis Haskell and Nicholas Penny, Taste $\mathcal{E}^{\circ}$ the Antique. The Lure of Classical Sculpture I500-1900 (New Haven: Yale University Press, 198I), p. 254.

II7 - Paraphrased by Baumstark, 'Das Nachleben der Reiterstatue', p. I07. II8 - Joseph Forsyth, Remarks on Antiquities, Arts, and Letters during an Excursion in Italy in the Years I802 and I803, I (3rd edn, London: John Murray, I824), pp. 250-I. Forsyth's assessment was confirmed by the laboratory

observation that the weight of the rider has deformed the horse's belly over time; Alessandra Melucco Vaccaro, Archeologia e restauro. Tradizione e attualitò (Milan: Arnoldo Mondadori, 1989), p. ı16.
II9 - Jacques Lacan, 'Some Reflections on the Ego', International foumal of Psycho-Analysis, 34, I (1953), p. 17. Thanks to my colleague Steven Levine for this reference.

I20 - Fittschen, in Fittschen and Zanker, Katalog, p. 72, initially described the head as a pastiche of Types 3 and 4, which entailed a date after 169 , hence a plausible association of the statue with the triumph over the Sarmatians and the Marcomanni celebrated in 176 . After the statue was cleaned he reclassified the portrait as a free copy of Type 3 alone, possibly influenced by the style of Commodus and therefore conceivably posthumous: Klaus Fittschen, 'Il ritratto del Marco Aurelio: considerazioni dopo il restauro', in Marco Aurelio, pp. 75-82.

I2I - Parisi Presicce, 'Il monumento equestre', p. 23; Wünsche, 'Der Kaiser zu Pferd', pp. 6I-2.

I22 - Barthes, 'Rhetoric of the Image', pp. $34^{-5}$. 